\title{
Test Excavations at Mission Concepcion Courtyard, San Antonio, Bexar County, Texas
}

Marty Krueger

Center for Archaeological Research

Frances Meskill

Center for Archaeological Research

Follow this and additional works at: https://scholarworks.sfasu.edu/ita

Part of the American Material Culture Commons, Archaeological Anthropology Commons, Environmental Studies Commons, Other American Studies Commons, Other Arts and Humanities Commons, Other History of Art, Architecture, and Archaeology Commons, and the United States History Commons

Tell us how this article helped you.

This Article is brought to you for free and open access by the Center for Regional Heritage Research at SFA ScholarWorks. It has been accepted for inclusion in Index of Texas Archaeology: Open Access Gray Literature from the Lone Star State by an authorized editor of SFA ScholarWorks. For more information, please contact cdsscholarworks@sfasu.edu. 


\section{Test Excavations at Mission Concepcion Courtyard, San Antonio, Bexar County, Texas}

\section{Creative Commons License}

\section{(c) (1) (8)}

This work is licensed under a Creative Commons Attribution-NonCommercial 4.0 International License 


\section{TEST EXCAVATIONS AT MISSION CONCEPCIÓN COURTYARD, SAN ANTONIO, BEXAR COUNTY, TEXAS}

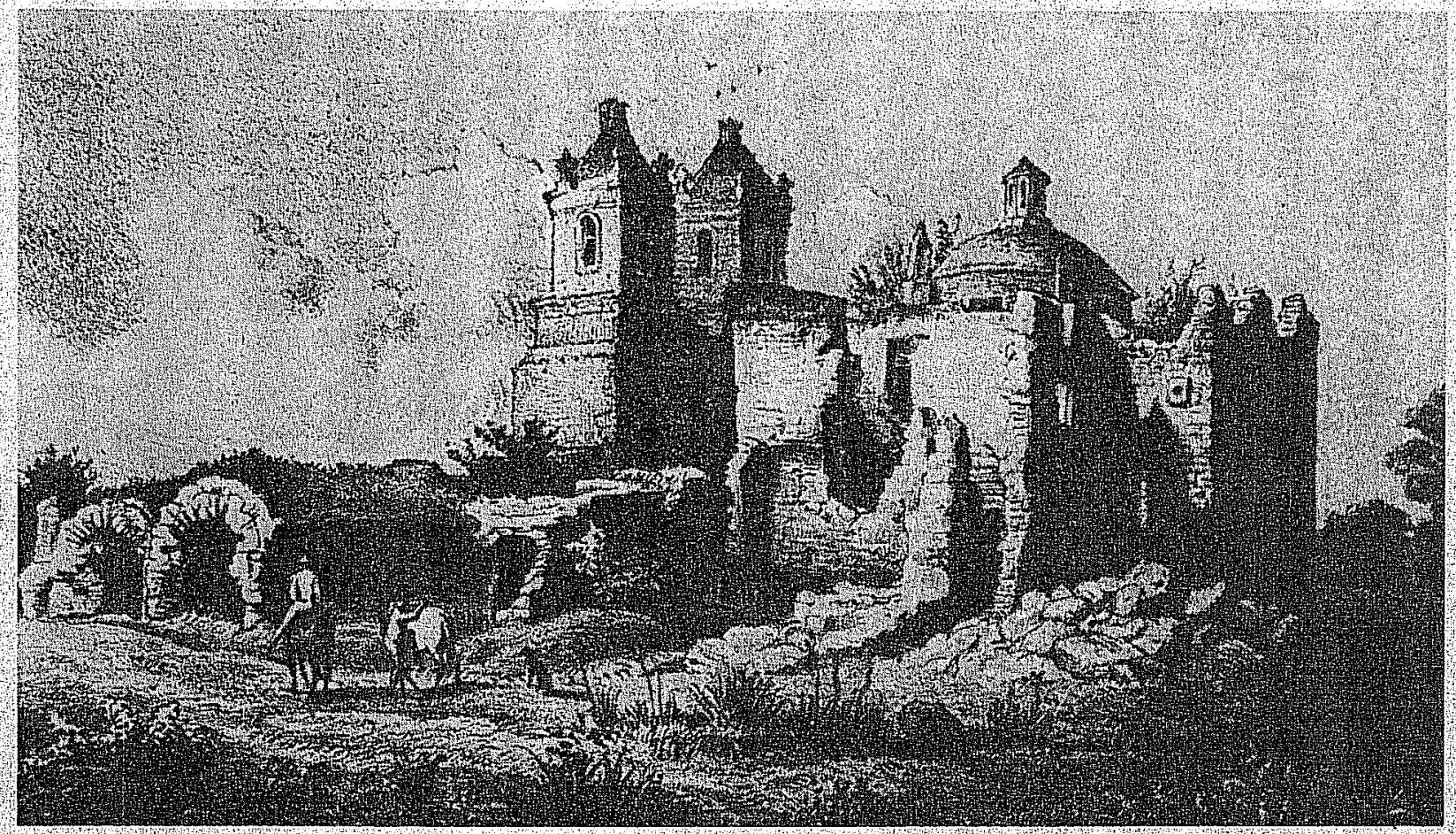

Marty Krueger and Frances Meskill

Center for Archaeological Research

The University of Texas at San Antonio Archaeological Survey Report, No. 214 



\section{TEST EXCAVATIONS AT MISSION CONCEPCIÓN COURTYARD, SAN ANTONIO, BEXAR COUNTY, TEXAS}

Marty Krueger and Frances Meskill

Texas Antiquities Committee Permit No. 956

Center for Archaeological Research The University of Texas at San Antonio ${ }^{\circledR}$ Archaeological Survey Report, No. 214 
The following information is provided in accordance with the General Rules of Practice and Procedure, Chapter 41.11 (Investigative Reports), Texas Antiquities Committee:

1. Type of investigation: Archaeological testing at Mission Neustra Señora de la Purísima Concepción;

2. Project name: Mission Concepción Courtyard;

3. County: Bexar;

4. Principal investigator: Jack Eaton, co-principal investigator: Anne A. Fox;

5. Name and location of sponsoring agency: San Antonio Missions National Historical Park, San Antonio, Texas;

6. Texas Antiquities Committee Permit No. 956;

7. Published by the Center for Archaeological Research, The University of Texas at San Antonio, Texas 78249-0658, 1992.

A list of publications offered by the Center for Archaeological Research can be obtained by sending $\$ 1.00$ to The Center for Archaeological Research, The University of Texas at San Antonio, 6900 N. Loop 1604 West, San Antonio, Texas 78149-0658. 


\begin{abstract}
In December 1990, the Center for Archaeological Research, The University of Texas at San Antonio, conducted limited test excavations at Mission Nuestra Señora de la Purísima Concepción de Acuña (41 BX 12) for the San Antonio Missions National Historical Park. The purpose of the excavations was to locate wall footings in the courtyard area, to increase the accuracy of maps from previous investigations so that future drainage and landscape work can proceed with greater confidence about where cultural material is located below the surface. The excavations showed the eastern arcade wall of the second convento to apparently be an uninterrupted wall, since arcade footings were not present. The western granary wall and the associated buttress were located. The excavations showed conclusively that the northern wall of the first convento did not extend eastward beyond the eastern arcade wall of the second convento, as had been previously projected. No traces of occupation surfaces were found. Our recommendation is that since the subsurface structural remains continue to offer complicated and sometimes surprising features, additional careful testing should be conducted before any potentially damaging work is begun.
\end{abstract}




\section{TABLE OF CONTENTS}

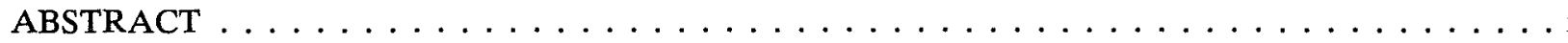

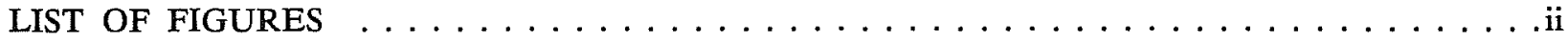

LIST OF TABLES $\ldots \ldots \ldots \ldots \ldots \ldots \ldots \ldots \ldots \ldots \ldots \ldots \ldots \ldots \ldots$ ii

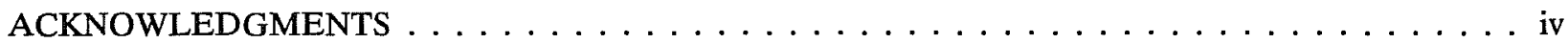

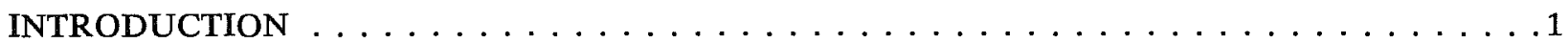

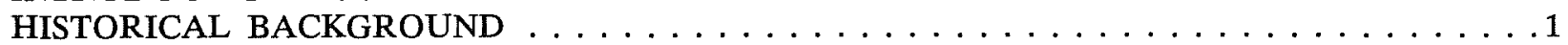

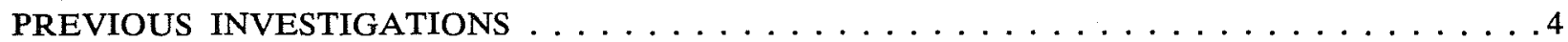

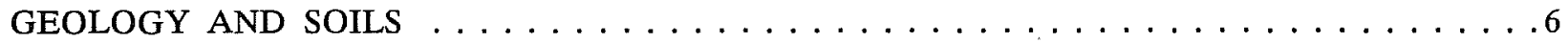

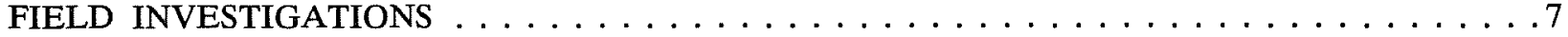

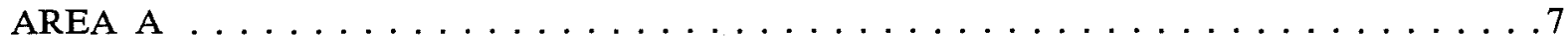

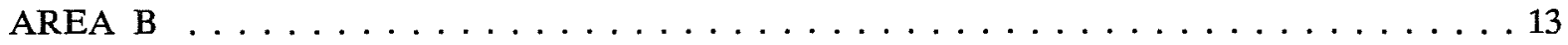

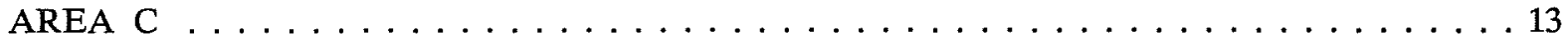

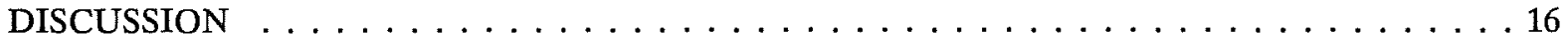

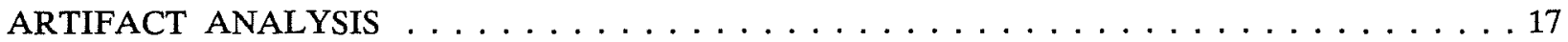

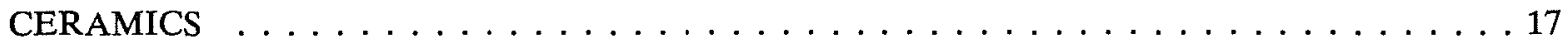

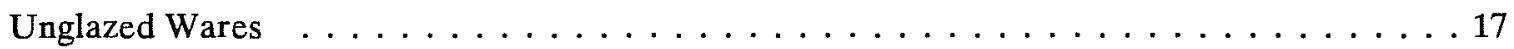

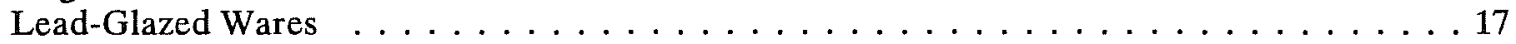

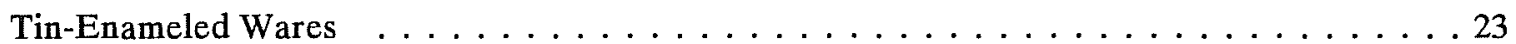

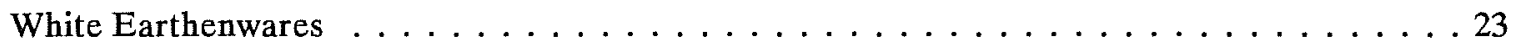

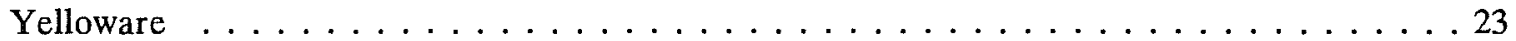

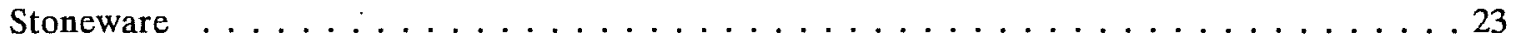

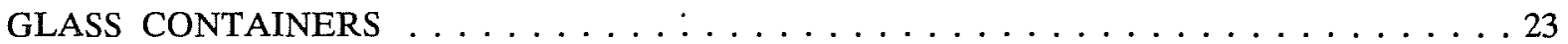

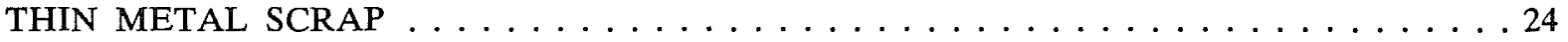

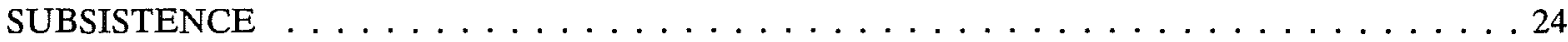

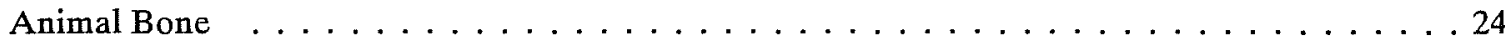

Mussel Shell . . . . . . . . . . . . . . . . . . . . . . . . 24

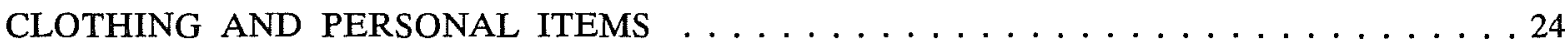

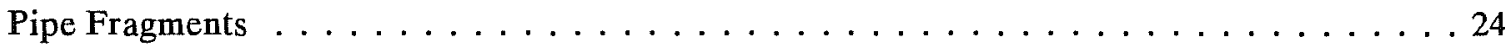

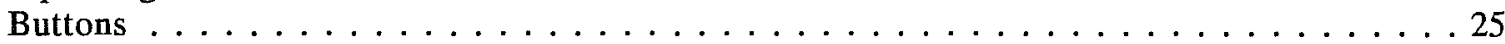

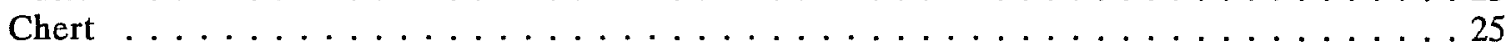

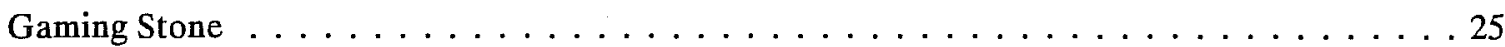

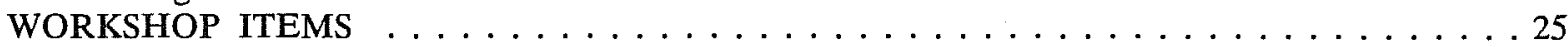

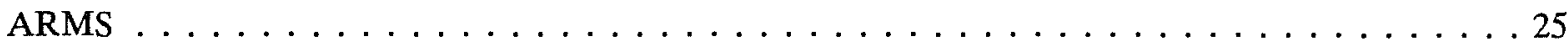

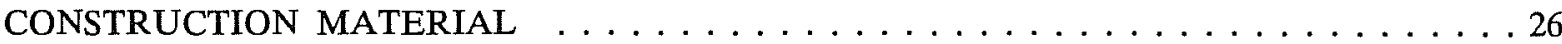

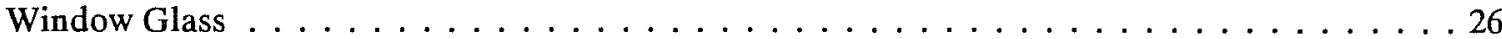

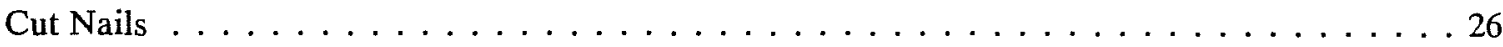

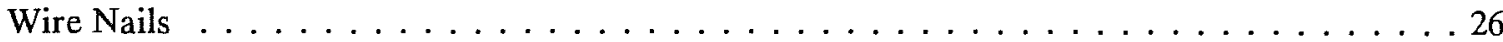

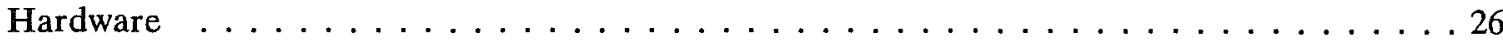

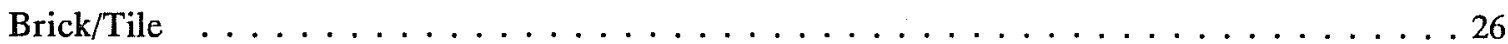

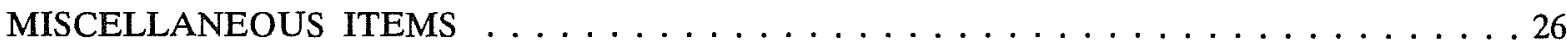

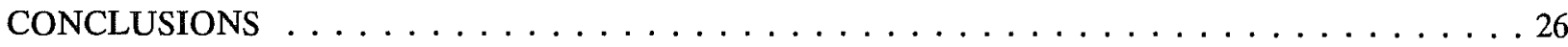

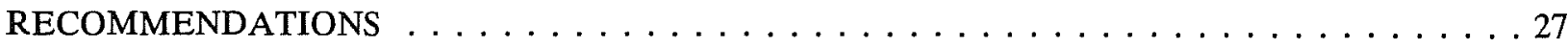

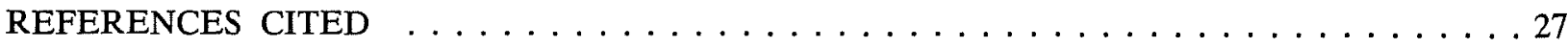

\section{LIST OF FIGURES}

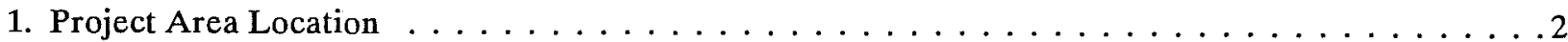

2. First Floor Plan of Church and Adjoining Structures $\ldots \ldots \ldots \ldots \ldots \ldots \ldots$

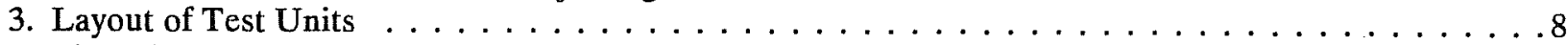

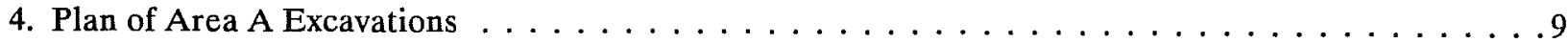

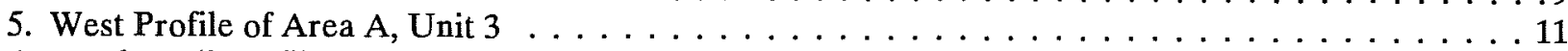

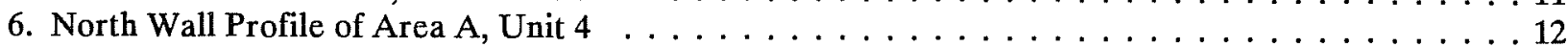

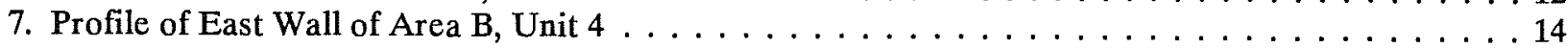


8. Level 2 Plan of Feature A in Area C Excavations, Unit $2 \ldots \ldots \ldots \ldots \ldots$

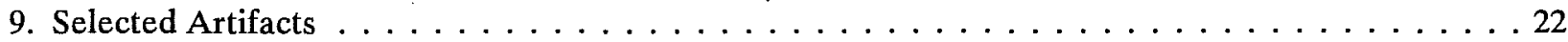

\section{LIST OF TABLES}

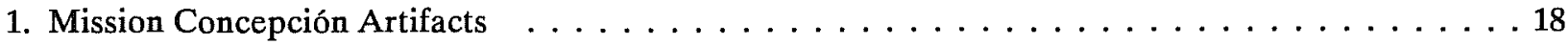




\section{ACKNOWLEDGMENTS}

In all it took over 420-person hours to complete the field work for this project. Volunteers contributed over half of the total time. We deeply appreciate and would like to thank the following volunteers: Herb and Kay Allison, Diane Couch, Ann Garland, Joan Lloyd, Don McEwan, Wilson McKinney, Marty Morrison, Bridget Smart, Burnley "Duke" Smith, Julia Spears, Tommy Tomesal, and Shirley Van der Veer.

Crew members included Clint McKenzie and José Zapata. Frances Meskill drafted the illustrations and wrote the Field Investigations and Chert sections, and John Poindexter photographed the artifacts. Special thanks go to Anne Fox for her assistance and guidance throughout the whole project and to Herb Uecker for backfilling the test excavations.

We would like to thank the staff of the San Antonio Missions National Historical Park and James Ivey of the Santa Fe office of the National Park Service for their cooperation, assistance, and insight. Evangelina Rubalcava, the park ranger at Mission Concepción, was most accommodating and helpful with the day to day operations.

Special recognition and thanks go to Los Compadres de San Antonio Missions National Historical Park for financing and enthusiastically supporting this project through to its completion. 


\section{INTRODUCTION}

The University of Texas at San Antonio's (UTSA) Center for Archaeological Research (CAR), in December 1990, conducted test excavations at Mission Nuestra Señora de la Purísima Concepción (41 BX 12), which is located about 2.5 miles south of downtown San Antonio (Fig. 1). Mission Concepción is part of the San Antonio Missions National Historical Park, and all work was done under contract with the National Park Service. The excavations were performed in compliance with Section 106 of the National Historic Preservation Act of 1966 (as amended) and Executive Order 11593. Texas Antiquities Committee Permit No. 956 was issued for the project. The project was financed by Los Compadres de San Antonio Missions National Historical Park.

The work was accomplished in eight working days by a crew of anthropology students and volunteers. The principal investigator for the project was Jack Eaton, acting director of the CAR, with Anne Fox as co-principal investigator; the field directors were Frances Meskill, Shirley Mock, and Marty Krueger. The project could not have been completed without the help of 13 volunteers who contributed over 225-person hours.

The purpose of the project was to determine what cultural resources may remain in the courtyard area of the mission. This was necessary in order that drainage work to alleviate periodic flooding and landscaping work might be accomplished with a better understanding of the layout of the mission to avoid accidental destruction of priceless historical information. Of particular interest were the following: the location of the eastern arcade wall and any associated doorways and pilasters; the location of the north and south walls of a storage room that apparently at one time occupied the space between the arcade wall and the granary; and to locate and examine a buttress against the west wall of the granary.

The challenge was to accomplish these goals with the most judicious use of time and personnel, while at the same time preserving the area's archaeological resources. All research notes, field and laboratory records, photographs, and artifacts from this project are curated at the CAR research laboratory at UTSA.

\section{HISTORICAL BACKGROUND}

A cursory overview of Mission Concepción is presented to set the stage for the importance of conducting detailed archaeological investigations in the vicinity. Father Marion Habig's (1968) book, The Alamo Chain of Missions, a History of San Antonio's Five Old Missions, will provide the interested reader with a detailed and readable source of information on the colonial mission experience in San Antonio.

Spanish colonial expansion was predicated on the success of missionary work by dedicated friars who took vows of poverty, providing the Spanish crown with a relatively inexpensive yet effective way to control vast territories. There were two institutions which trained and administered Franciscans friars working in Texas, the colleges of Querétaro and Zacatecas. These colleges were dedicated to St. Francis, the son of a prosperous merchant who abandoned a carefree life style spent in the pursuit of pleasure for one of simplicity and poverty dedicated to the service of God.

The concept of the mission was never intended to be a permanent facility run by the friars. Rather, after the missionary work of converting the local Indians into Christian Spanish citizens was completed, the mission lands were to be turned over to the Indians and the Franciscans moved to another location to continue their work.

Mission Nuestra Señora de la Purísima Concepción de Acuña was established in 1731 on the east bank of the San Antonio River, 2.5 miles south of Mission San Antonio de Valero. It was originally named Mission Nuestra Señora de la Purísima Concepción de los Hainai when first established in East Texas on July 7, 1716, on the Angelina River in Nacogcoches County (Habig 1968:119). The mission was primarily established in response to French incursions into Louisiana and East Texas. 


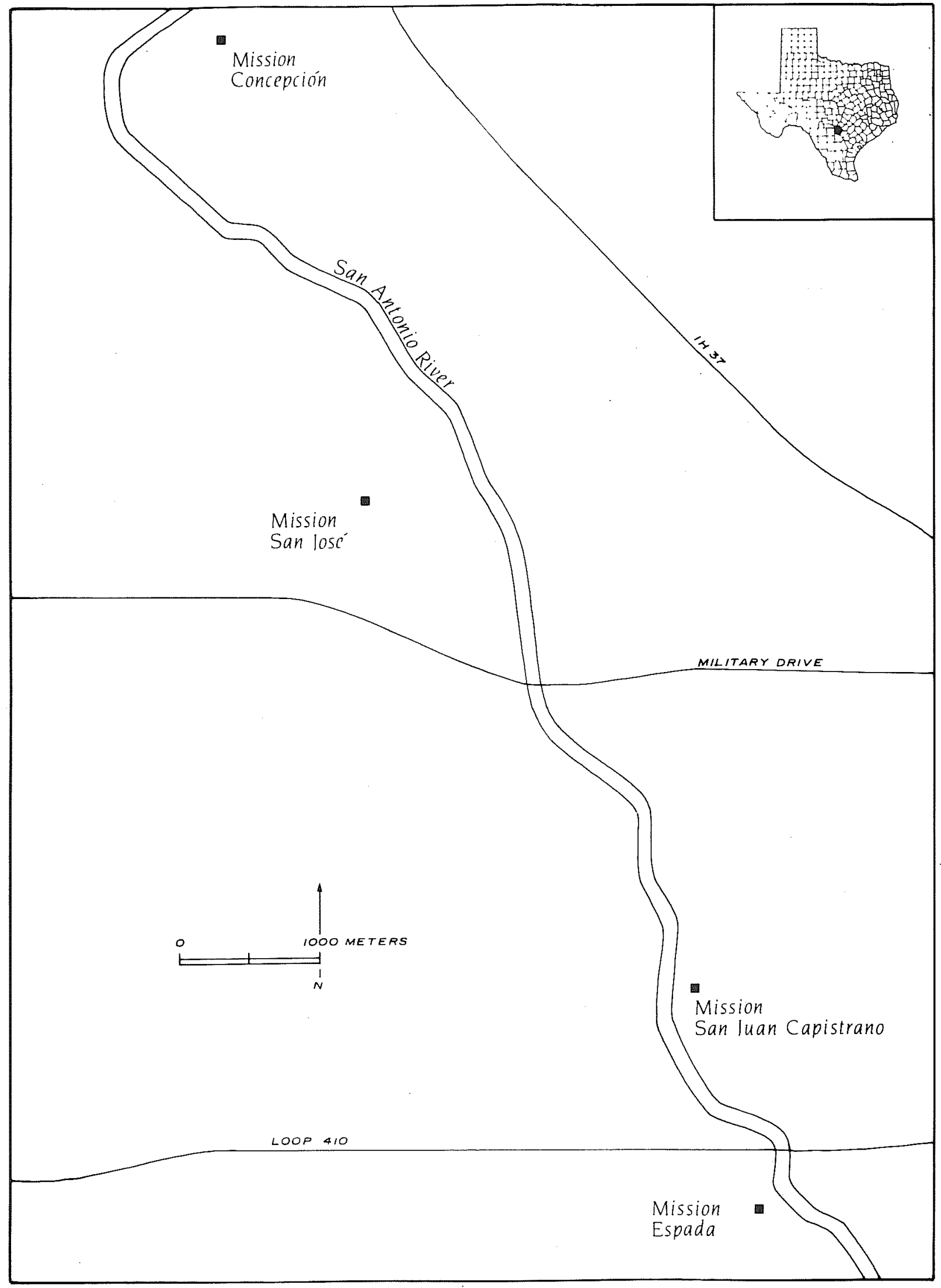

Figure 1. Project Area Location. 
After the French ceased to be a threat, and the mission was not successfully converting the local Indians, the Viceroy was petitioned to move the mission to a more suitable location. The mission was moved to the Colorado River on July 27, 1730. However, the site was not satisfactory, so the friars requested and received permission to move to the San Antonio river. The re-establishment began on March 5, 1731, though the temporary jacal (vertical log construction) buildings were not completed until May 4 of that year (Habig 1968:124).

About 300 Coahuiltecan Indians of the Pajalat and Pacao bands were persuaded to take up mission life in San Antonio. Three soldiers from the presidio at La Bahía (Goliad) were stationed at Concepción to help maintain order among the new converts, to help the missionaries in their work with the Indians, to be an added defense against the marauding Lipan Apaches, and to assist the padres in acquiring new converts and returning runaways (Scurlock and Fox 1977:6).

Corn, beans, watermelons, sweet potatoes, pumpkins, and a variety of fruit trees were grown on the mission farm located on the east bank of the river, just west of the compound. The farm was irrigated by an acequia system (irrigation ditches) and worked by 30 oxen kept at the mission (Scurlock and Fox 1977:7). The mission also maintained a ranch called El Paxtle or El Pasthle (Scurlock and Fox 1977:7) probably located in the Cibolo Creek valley 12 leagues east of the mission, where about 700 head of cattle, 800 sheep, 12 pigs, and a herd of horses were kept (Habig 1968:133).

The stone church was begun about 1735 . However, in the meantime services were held in an adobe structure with a flat earthen roof and a sacristy (Ortiz 1745:1272). By 1745, the mission was surrounded by a stone wall and consisted of a stone granary, three stone houses for the soldiers, a two-story stone convento with offices for the friars on the first floor and sleeping quarters on the second, and jacal Indian quarters (Ivey and Fox 1982:73). The church was completed by 1755. In 1756 the first stone convento was partially in ruins, and construction on the present convento began (Ortiz 1955:35). With the present one-story convento nearly complete in 1762, the vacated convento building was partly used for cooking activities - at least by the mission Indians (Ivey and Fox 1982:75).

Mission Concepción was under construction at a time when there was a philosophical revolution occurring in the relationship between the friars and the Indian population. In contrast to the convento at San Antonio de Valero, which began construction ca. 1724 and was based on the earlier plan where conventos were enclosed squares facing an inner courtyard, the convento at Mission Concepción was built in the same plan as those constructed in California after 1769 , where conventos faced outward towards the Indian pueblo or onto the surrounding fields (Ivey and Fox 1982:74).

Despite the contributions and advances of the mission, it was failing in its primary purpose of forming a perpetual community of Christianized Indians. By 1740, there were 200 Indians at Concepción, but by 1794 only 38 Indians remained (Scurlock and Fox 1977:6). The decline of the mission was hastened by several economic misfortunes. There were increased attacks by hostile Indians; in 1767 most of the horses were stolen leaving 1200 head of mostly unbranded cattle to roam uncontrolled. In 1778 Commandante General Teodoro de Croix decreed all unbranded cattle the property of the government. This represented a major loss to the mission (Habig 1971:8).

In 1767 , the Jesuits were expelled from all Spanish holdings and their missions were turned over to the college of Querétaro. The Queréterans on December 16,1772, in turn transferred their missions in San Antonio to the Zacatecans who administered the mission operations from their own mission San José (Habig 1968:136). After the transfer, most of the construction stopped at Concepción and in 1780 the Zacatecans began to prepare for the impending change in status of the San Antonio missions from reduccion to doctrina, a step referred to as partial secularization (Leutenegger 1973:31).

Partial secularization began in 1794 with the transfer of all the worldly goods of the mission (except for the vestments and religious articles), including the land and houses to the 38 Indian occupants of the pueblo. They were then eligible, as free, Spanish property-owning citizens, to pay tithes and taxes to the secular church (Matson and Fontana 1977:13-14). By 1819, the church congregation had dwindled to the point that 
church services were suspended, and in 1824 with the final secularization, the Zacatecans closed Mission Concepción and turned over the church and property to the pastor of San Fernando church (Habig 1968:146).

The Mexican government was selling surrounding lands to local citizens even before secularization was official. Manuel Yturri y Castillo purchased the granary in 1823 and lived there with his family until he sold it to Asa Mitchell in 1838. Mitchell apparently never occupied it (Ivey and Thurber 1984:3-61).

During the period from 1810 to 1836, just prior to and including the Texas revolution, Concepción was host to some important military events. In 1813 Bernardo Gutierrez and his revolutionary army from La Bahía headquartered at Concepción as they prepared to lay siege to the presidio of San Antonio de Bexar. However, the siege was unnecessary. On April 2, Governor Saucedo surrendered the city, and "the flag of the short lived first Republic of Texas was hoisted in Military Plaza” (Habig 1968:144).

In 1825, with about 50 families living in and around Concepcion, troops were sent to deter Apache raiding in the area (Habig 1968:147). The Battle of Concepción in 1835 was fought when James Bowie, headquartered at the mission, met and defeated Mexican troops in a nearby bend of the river (Habig 1968:148).

Following the Texas revolution the convento was used or rented out as a residence by Ramón Músquiz, the governor of Texas and Coahuila in 1835-1836, and the church was used by local farmers as a cattle barn (Webb 1952:253). After Texas was annexed by the United States in 1849, the U.S. Army used the church as a depot and reportedly cleaned out rubbish and cow dung over a foot deep (Corner 1890:6).

Bishop Odin, realizing that the future of the Catholic Church in San Antonio rested in education, convinced the Brothers of Mary to open a school at Concepción in the early 1850s. The Brothers restored and reopened the church for services in May 1861 (Ivey and Fox 1982:76). In 1911, the Brothers turned over title to the mission to the Bishop of San Antonio in exchange for land and a school downtown. At this new location their school became present-day St. Mary's University (Schmitz 1965:20). Soon thereafter, St. Peter's-St. Joseph's home, an orphanage, was built southwest of the mission. St. John's Seminary was built northeast of the mission in 1919 (Scurlock and Fox 1977:11).

The Redemptorist Order took charge of Concepción in 1922 and began a period of structural stabilization, restoration, and landscaping. Among other things, they added a buttress to the east wall of the convento and introduced palm trees and other exotic plants (Fox 1988:6).

Until recently, Sunday mass was still held in the Concepción church, and the grounds have been open to the public since the 1950s. The 95th Congress passed Public Law 95-629 on November 10, 1987, placing the mission, except for the church and sacristy, under the administration of the National Park Service and establishing the San Antonio Missions National Historical Park (Cisneros 1980). Mission Nuestra Señora de la Purísima Concepción de Acuña is now a State Archeological Landmark, a National Historic Landmark, and is listed on the National Register of Historic Places.

\section{PREVIOUS INVESTIGATIONS}

In the 1930s, local architect Harvey P. Smith, working with the Works Progress Administration (WPA), directed excavations around the standing mission structures and mapped numerous buried foundations south of the convento (Fig. 2). Much of the subsequent archaeology has been based on his drawings.

During 1971 and 1972, the Texas Historical Commission conducted investigations to test the moisture content and structural integrity of the mission church, to locate the west wall of the mission, and to investigate the area south of the convento (Scurlock and Fox 1977).

Since 1981, the San Antonio Missions National Historical Park has contracted a series of investigations with the CAR to excavate test pits for specific purposes in response to the needs of maintaining and interpreting 
SCHEDULE or ROOMS (1) NAVE - BRICK FLOOR, PLASTER WALLS AND CELLING.
(2) CHANCEL- BXB. YELLOW AND OVER PLASTERED. (3) SANCTUARY-YELLOW AND BLACK AND CEILING.
(4) TRANSEPTS - FINISHED SIMALAR TO(3)
SACRISTY-BRICK FLOOOR, PLASTER (6) BAPTISTRY - BRICK FLOOR. WALLS (7) TOWER ROOM - SIMILAR TO (6) (8) KITCHEN-DIRT TLOOR. PLASTER (9) STORE ROOM-DIRT FLOOR.WALLS (19LIVING ROOM-BRICK FLOOR. WAL (11. LIBRARY CEING SLASTERD (12) CLOISTER-BRICK FLOOR. STONE WALLS AND CEILING. NOTE: ROOMS 5. TO II. WERE AT ONE TIME DECORATED WITH WAL AT ONE DISTINGUISHABLE NOW.

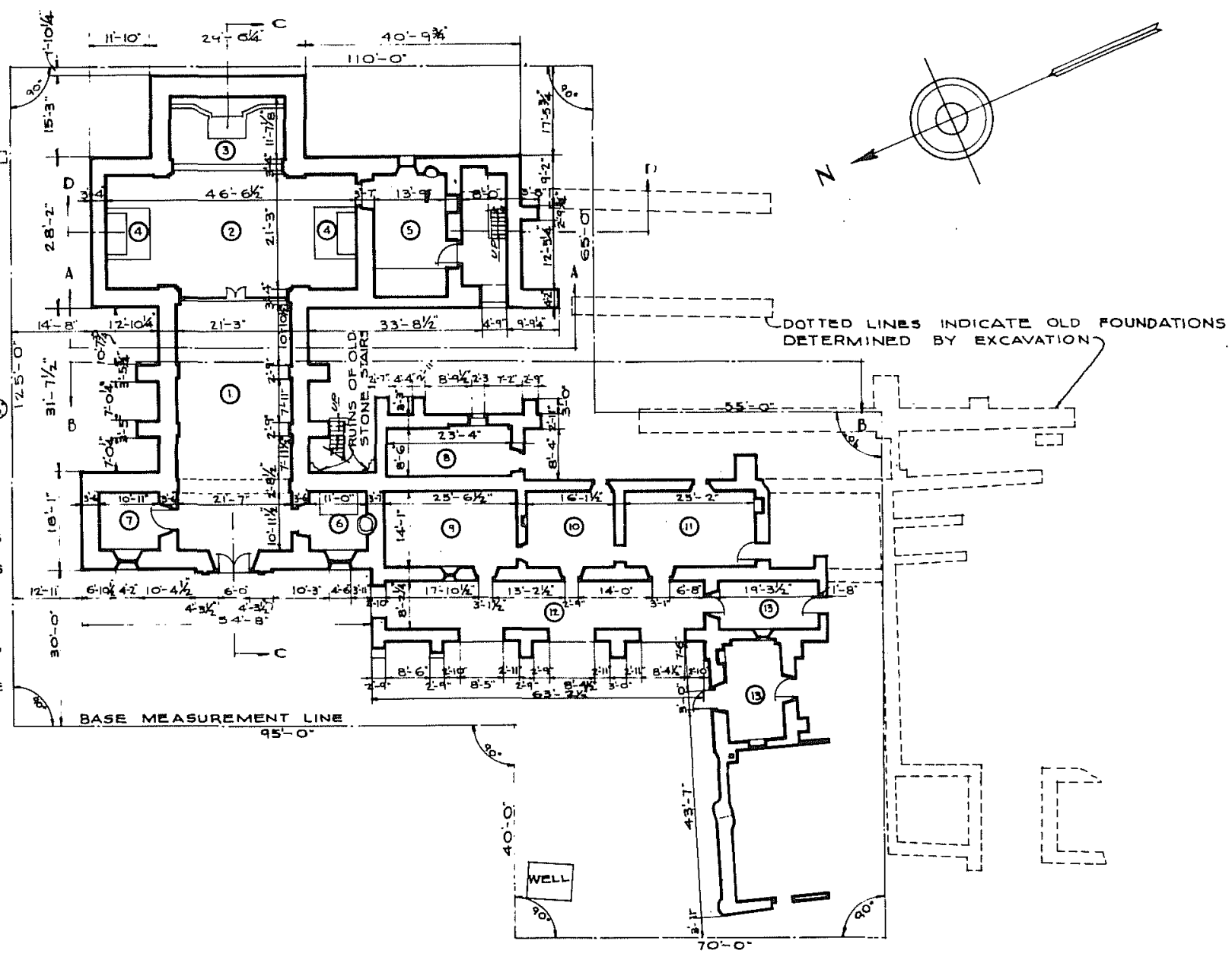
FIRST FLAOOR PLAN

WELTON COOK. DEL WOAKS PROGRESS ADMINISTRATION UNDER DARECTION FE UNITED STATES DEFANTMENT OF THE INT

MISSION LA PURISIMA COME OF STRUCTURE

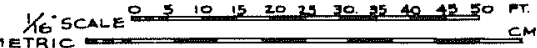

NA $\quad$ SURVEY HO

Figure 2. First Floor Plan of Church and Adjoining Structures. Taken from Scurlock and Fox (1977:Fig. 10). 
the mission. In 1981-1982, selective excavations were conducted in order to locate the original outer walls of the mission, the granary, and the Indian quarters along the walls of the pueblo (Ivey and Fox 1982). From the excavations at the south end of the granary, Ivey was able to suggest a sequence of building events starting with the demolition of an adobe structure, the subsequent building of a stone structure over the adobe debris, and ending with an early 19 th-century house being built over all the previous structures.

In October 1986, as a result of periodic flooding in a low area between the sacristy and the convento, test excavations were conducted to determine the least archaeologically destructive route for a drain pipe to eliminate the problem (Fox 1988). This excavation revealed the foundations for a two-story convento that stood until the 1760 s when the present convento took its place.

As a result of plans to relocate Mission Road to its original 18th-century position, in February 1987, excavations were conducted outside the west wall of the mission. In the 1950s and 1960s, under the direction of a priest from the orphanage, the project area had been bulldozed to provide a level playing field for the children. Unfortunately, this left no significant evidence of deposits or structural remains in the area around the southwest corner of the mission compound (Labadie 1989:2).

The second phase of the Mission Road realignment project called for archaeological investigations in October 1988. These excavations located the west wall of the quadrangle and remains of an adobe structure with an associated hearth feature on the interior of the wall. It was estimated that the northwest corner of the quadrangle wall was beneath the current Mission Road (Brown n.d.). This was confirmed by subsequent backhoe testing (Fox 1992).

Construction related to the installation of new air conditioning in the church was monitored by CAR in July 1988 (Fox 1989). As a result of communication and cooperation between the archaeologist, the architect, the contractor, representatives of the National Park Service, and the Texas Historical Commission, the project was successfully completed without serious damage to any cultural remains.

The accumulation of knowledge about the construction and workings of Mission Concepción through previous archaeological investigations has been instrumental in the planning, execution, and analysis of the present testing operation.

\section{GEOLOGY AND SOILS}

Mission Concepcion is located on a low knoll where at the time of construction it would have been possible to view the entire San Antonio River valley for some distance to the north and south. The present (rechanneled) San Antonio River is approximately one-half mile to the east of the mission. In the 18th century, the natural river channel, now included in Concepción Park, was located approximately 500 feet to the west of the mission.

The site is located in an area of Venus-Frio-Trinity Association soils, which are mostly grayish brown alluvial soils (Taylor, Hailey, and Richmond 1966). The ridge itself is classified as Hilly Gravelly Land (HgD) by the Soil Conservation Service and is composed of cemented calcium carbonate sediments (locally called caliche) 10 to 20 feet or more in thickness (Taylor, Hailey, and Richmond 1966:17). Soils in the compound area are shallow, exhibiting an A-C horizon development, as a result of having travertine (limestone) bedrock close to the surface and from the impact of human habitation that precluded the development of garden spaces. Midden areas invariably exhibit a dark brown soil color as a result of organic enrichment, as opposed to the lighter colored soil of nonmidden areas (Scurlock and Fox 1977:33).

In addition to the slight elevation, other advantages of the site location are the extensive travertine deposits located on the southwest edge of the compound and the shallowly buried caliche for support of the building foundations. The limestone outcrop was quarried for building material for this mission, other area missions, and later buildings in the area. The care taken in the site selection is reflected in the structural integrity of 
the church at Concepción, which has not collapsed at any time in the past, unlike other mission churches in the area which have experienced extensive structural problems.

\section{FIELD INVESTIGATIONS}

The CAR-UTSA field investigations concentrated on three areas within the courtyard south of the church at Mission Concepción. The locations of the units were designed by the National Park Service in order to maximize information on specific structural features and to determine areas of least disturbance for impending ground modifications. CAR's assignment of Areas A, B, and C in the study correspond (Fig. 3), respectively, to Areas 1, 2, and 3 as stipulated within the National Park Service guidelines.

Objectives for Areas A and B focused on documenting evidence for the eastern wall of the convento and for the north and south walls of the officina de habasato comun (community storeroom), which is believed to have been situated within the courtyard, between the convento and the granary (James Ivey, personal communication). Excavations at Area $C$ were concerned with locating the west wall of the granary and a possible buttress for the wall. CAR investigators studied the measured WPA map supervised by Harvey $\mathbb{P}$. Smith in order to size and position the areas so that recovery of structural data would be optimized within the restricted time allotted for the investigations.

Excavations were conducted using the metric system, with each block taken down in 1- $x$ 1-m units. Vertical control was maintained using $10 \mathrm{~cm}$ levels, or levels were sometimes dug by cultural or natural strata if a distinct change in matrix was noted before the $10 \mathrm{~cm}$ depth was achieved. All material was screened through 1/4-inch hardware cloth and bagged by provenience.

Daily logs were kept, and information for each unit was recorded on standard level forms. Field drawings, black and white photographs, and color slides documented each phase of work and the significant features. All records are on file at CAR-UTSA.

\section{AREA A}

Area A consisted of a 4- x 2-m block situated at the eastern convento wall (or arcade); it was located largely within the dining room identified in Smith's drawing (Fig. 3). The northwest corner of Area A was positioned $3.75 \mathrm{~m}$ south of the exterior wall of the kitchen and $2 \mathrm{~m}$ east of the extant section of the convento; its long axis lay north-south, parallel to the length of the convento.

The investigations at Area A focused on locating the following: (1) foundations of the east wall of the arcade; (2) any arcaded opening or pilaster associated with the wall; and (3) possible evidence of the north wall of the storeroom, which was reportedly located east of the convento.

During the investigations, seven of Area A's eight 1- x 1-m units were excavated (Fig. 4). Units 1, 2, and 3 were taken down to levels where little or no artifactual material had been yielded, with only 12 artifacts (of a total of $\mathbf{4 3 3}$ for the three units) collected from the lowermost layers. Artifact density had also decreased markedly in the final level excavated in Unit 6. Units 5 and 8 were excavated to the floor of Level 2 only (20 $\mathrm{cm}$ ) due both to time restrictions and, in the case of Unit 8, lack of evidence of structural features and the disturbed condition of the unit.

Wall foundations for the eastern face of the convento were quickly discovered in Units 1 and 2 , at the southwest section of the excavations (Fig.4). The upper reaches of the rock alignment were seen close to the surface, at $3-13 \mathrm{~cm}$ depth, and the northern edge was located $5.88 \mathrm{~cm}$ south of the kitchen's exterior wall. This foundation wall had been documented by Harvey Smith during the WPA investigations as far north as into Unit 2; the CAR excavations appear to extend the location of the wall some $0.50 \mathrm{~m}$ north beyond that outline (refer to Fig.2). 


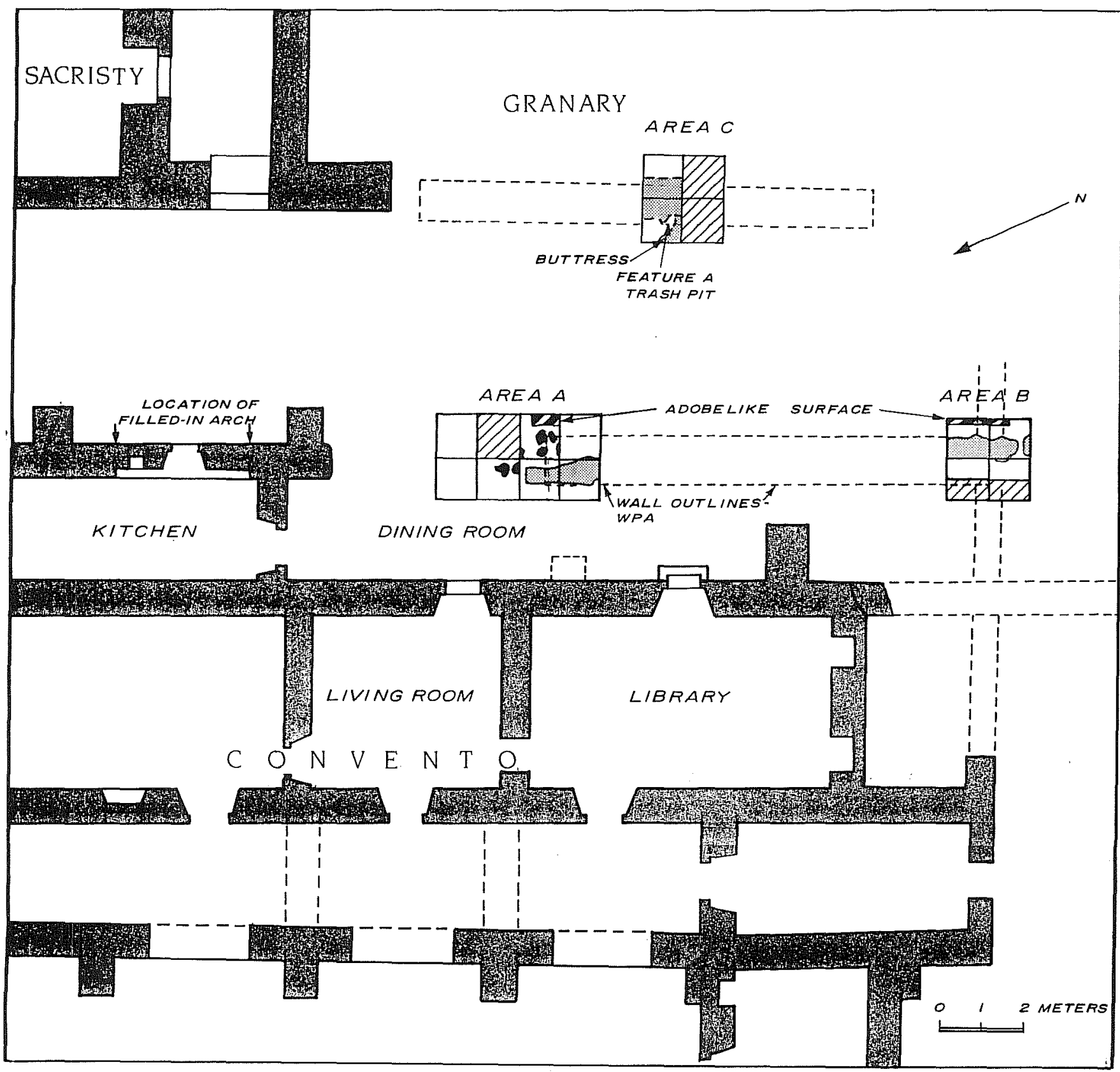

Figure 3. Layout of Test Units. 


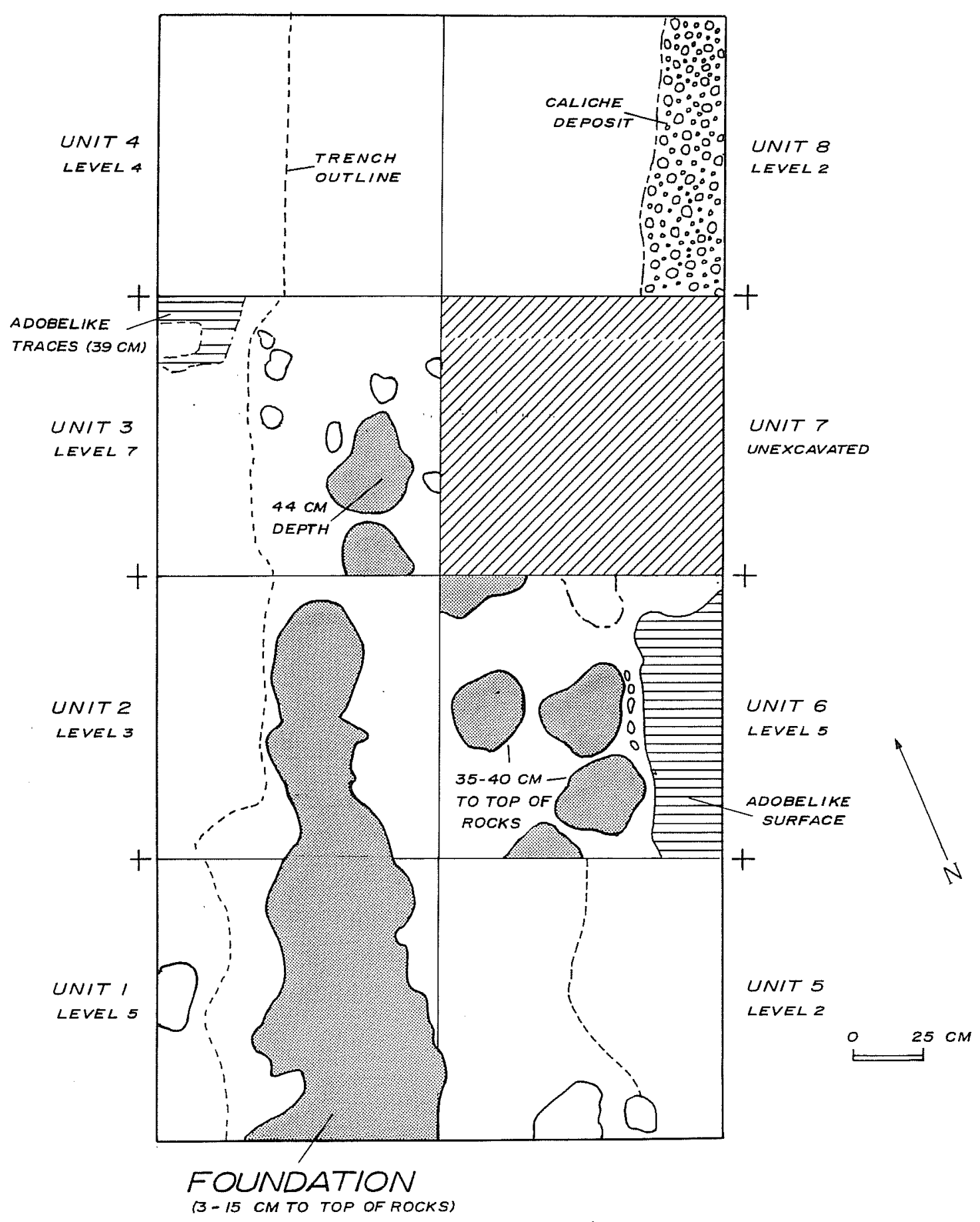

Figure 4. Plan of Area A Excavations. 
No conclusive evidence was found to support the existence of an arch in Area A, although support for the existence of a possible doorway opening or arch situated before the dining room door was suggested by the initial discovery of the northern edge of wall stones in the upper strata of Unit 2. The trench outline to the north of this edge indicates, however, that the area was stone robbed. Additionally, rocks were exposed at lower reaches, at a depth of 44 to $60 \mathrm{~cm}$; and these appear to be a continuation of the east convento wall toward the north.

Mixing of temporally diagnostic materials was seen in the upper two strata in Area A, particularly in Level 1; here a variety of artifacts were found, including Spanish colonial Goliad ware and majolicas, along with more recent materials. The upper layers were no doubt disturbed in order to expose wall outlines during the documentation by the WPA; and ground modifications, stone-robbing, and other events likely had previously churned the deposits. The topography of the area suggests that the Area A and B sections may have been lowered somewhat during the mission's history, perhaps in efforts to correct drainage conditions that are still problematic.

The eastern margin of the foundation wall was not found at the upper levels of the CAR excavations, but at a depth of $35-40 \mathrm{~cm}$ in Unit 6 several rocks (measuring about $25 \mathrm{~cm}$ in length) were discovered. These rocks are likely remains of the eastern edge of the foundation.

Excavations in Unit 3 were of particular interest, although the deposition was complex and difficult to interpret. Deposits that are apparently roof (or perhaps vaulting) fall were exposed in the western section of Level 2 in Units 2 and 3; the deposit is deeper toward the west wall (its downward slope can be seen in the west profile of Unit 3; Fig. 5). Its slope and continued occurrence into the trench edge suggests that the fall probably occurred previous to the digging of the trench, which was judged to have likely been cut in order to rob the wall stones for reuse. Stone robbing of the convento was known to have been authorized as early as 1841, in order that San Fernando Cathedral might be refurbished (Ivey, Thurber, and Escobedo 1990:222).

The episode of roof/vaulting fall was heavy in the west walls of Units 2,3 , and 4, measuring some $20 \mathrm{~cm}$ in thickness, with a depth of approximately 10 to $32 \mathrm{~cm}$. Less extensive evidence of the fall appeared in Unit 1 . The loose, yellowish fill (10 YR 7/3 - very pale brown) was composed of small rock fragments and gravels, bits of mortar and adobelike remnants, within a sandy matrix. The fill was distinctly thicker at the western edge of the units.

Sterile fill was discovered at about $32-34 \mathrm{~cm}$ down in the west section of Units 1-4. This appears to be the original matrix that lay outside of foundation and robber trench outlines; it consisted of a dark grayish brown (10 YR 4/2) soil, compacted and more claylike. The trench outline was recorded some $20 \mathrm{~cm}$ from the west wall in Unit 1, Level 4, and observed at approximately 30 or more from the west wall in Units 3 and 4 (Fig. 6). This slight shift in the trench outline might possibly be interpreted to support an arch construction in the area of Units 3 and 4. However, the presence of a stone-robbed footing trench through the area argues against this.

A thick (7-9 cm), consolidated, adobelike surface was exposed along the east wall of Unit 6 in Area A (Fig. 4). This surface may represent remains of the flooring of the storeroom, although no traces of the storeroom wall were found. Because of the exigencies of time, Unit 7 was left unexcavated and it is possible that the storeroom wall could have been exposed at that location or at a greater depth in Unit 8. A surface exposed in Area B (see the following section) may be associated with the southern extension of the storeroom flooring, or the surface may be part of Room 3, which was documented by Ivey during the 1981 excavations (Ivey and Fox 1982:Fig. 4).

An intrusive deposit of caliche gravels (10 YR 8/2, white, to 10 YR $7 / 2$, light gray) was exposed along the east side of Unit 8 in the first level, continuing down through Level 2 . The deposit was approximately $30 \mathrm{~cm}$ wide (Fig. 4). 


\section{WEST PROFILE OF AREA A, UNIT 3}

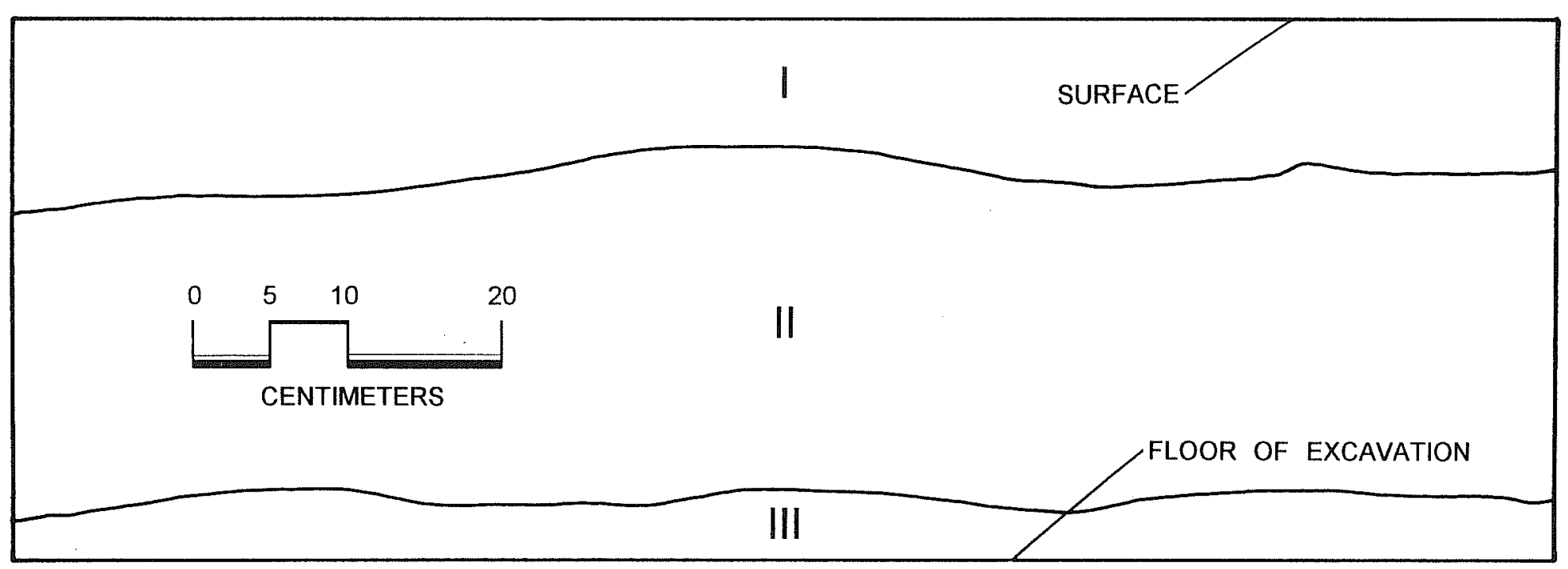

STRATUM I $(0-10 \mathrm{~cm} ; 10 \mathrm{YR} 5 / 1)$. Medium to light gray sandy-clay loam.

STRATUM II $(10-30 \mathrm{~cm}$; 10YR 5/2). Light yellow clay with fine limestone gravels, iron stains, and white caliche.

STRATUM III $(30-35 \mathrm{~cm}$; 1OYR $5 / 4)$. Finely laminated medium gray sandy-clay loams.

Figure 5. West Profile of Area A, Unit 3. 


\section{AREA B}

Area B was laid out with its northwest corner $16.75 \mathrm{~m}$ south of the kitchen wall and $2 \mathrm{~m}$ east of the projected extension of the convento aligned with Area A (Fig. 3). Objectives here were to locate the eastern arcade wall and a possible pilaster supporting it, and, additionally, to find evidence of the south wall of the community storeroom.

The Area B excavations consisted of a 2- x 2-m block, divided into four 1- x 1-m units. Units 3 and 4 were taken down to $30 \mathrm{~cm}$ depth, while Units 1 and 2 were excavated on the eastern half only to a depth of $10 \mathrm{~cm}$; time limitations precluded further excavation in these two units.

The southern extension of the east wall of the convento was exposed in Units 3 and 4 in the $50 \mathrm{~cm}$ or more at the western half of the units. Although the suggestion of an intersecting wall from the east was seen in the upper level of Area B, the rocks were loose and judged to be wall fall, and were removed. No trace of wall or footing was found beneath them.

No other indications of a possible storeroom wall were found in Area B. At the eastern edge of Units 3 and 4 , however, at a depth of approximately $25 \mathrm{~cm}$ (below the rock fall), was found an adobelike (or perhaps plaster) surface (Fig.7). It could represent remnants of the same flooring observed in Area A, Unit 6, although the surface in Area B appears to be approximately $7 \mathrm{~cm}$ higher and is generally quite thin. One thick section of the surface was present at the center of the unit. The feature could also represent a continuation of the plaster surface observed by Ivey (Ivey and Fox 1982:Fig. 4) during 1981 investigations within Room 3, which is located between the convento and the room south of the granary. The east corridor wall found in Area B could well have served as the west wall of Room 3.

As in Area A, there was a mix of artifacts through time in the upper two strata of Area B, with Spanish colonial as well as early and late 19 th-century ceramics present, along with cut and wire nails, a wood screw, and other materials. Level 3 appeared to be relatively undisturbed by later materials; here the artifacts are largely Spanish colonial in date (Goliad ware, a lead-glazed sherd, ladrillo fragments, bone, and, interestingly, a modified sandstone gaming piece). Two pieces of undecorated whiteware, however, were also found at this level, and these could date to the mid to late 19th century.

The south wall of the storeroom (and/or the north wall of Room 3) was not found in the Area B excavations. Figure 4 from Ivey (Ivey and Fox 1982) indicates that the wall may be situated slightly north of the Area B.

\section{AREA C}

Excavations at Area $\mathrm{C}$ focused on defining the location and width of the west granary wall, and on verifying the presence of a buttress posited for the wall. The area was positioned $8 \mathrm{~m}$ east of the extant wall of the convento and $1 \mathrm{~m}$ south of the south wall of Area A. Of the four 1- $\mathrm{x} 1-\mathrm{m}$ units constituting Area $\mathrm{C}$, only the northernmost units (Units 2 and 4) were excavated (Fig. 3).

Within these units were documented the granary wall and its buttress, although the wall's full width may not have been exposed. A small trash pit was discovered in Unit 2, Feature A (Fig. 8), intruding into the buttress. The cultural deposits located within Area C appear to be more intact than in either Areas A or B; the topography of the section suggests that major ground modifications may have been effected in the latter two areas, perhaps in efforts to correct still extant drainage problems.

The upper 3-8 cm of Units 2 and 4 contained a matrix of red sand, reportedly deposited in the 1980s as the base for a brick walk which is no longer in place; the red deposit was generally deeper on the west side. A rock mass, apparently representing the granary wall, was discovered at the bottom of Level 1 along the east side of Unit 2. 


\section{AREA B}

UNIT 4 - East Wall Profile

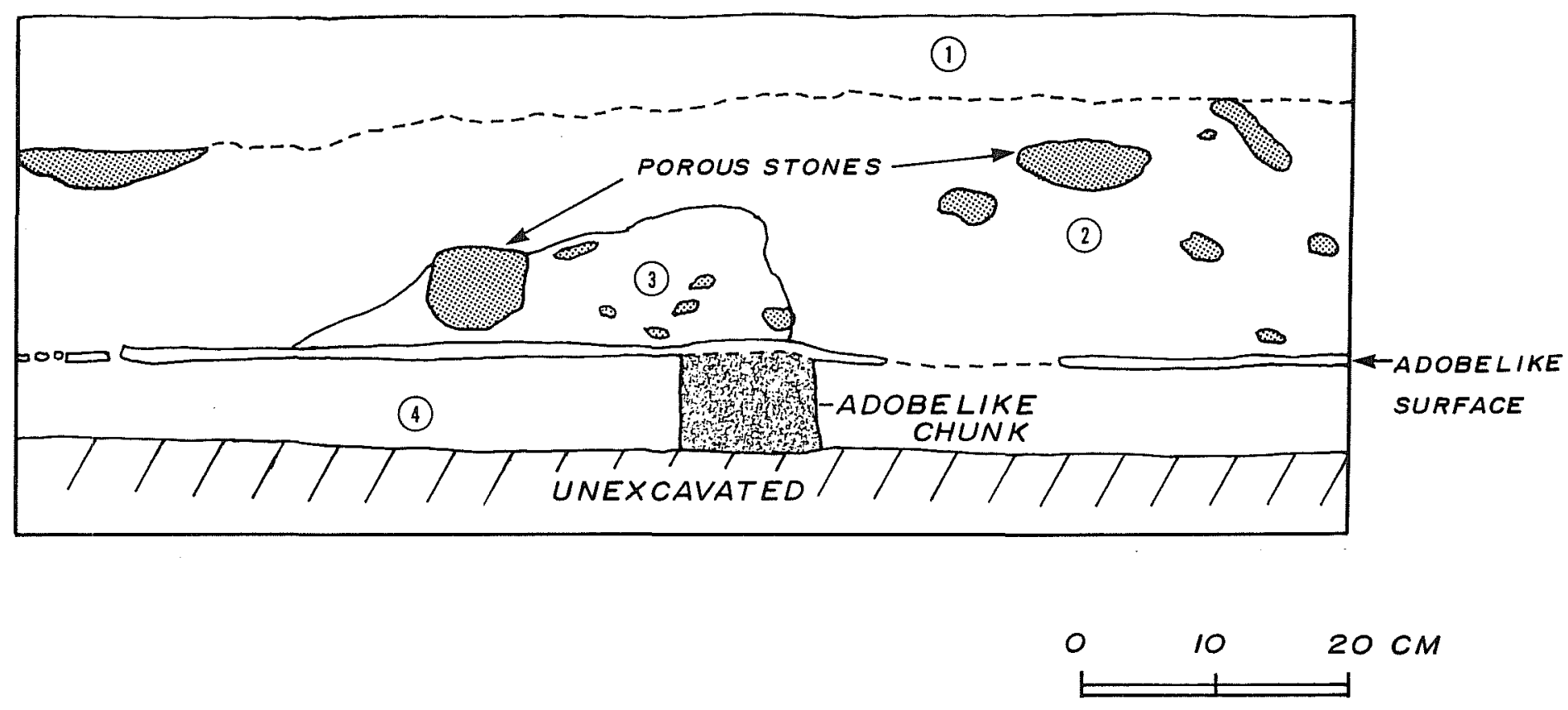

1-Gray loam having roots and small pebbles; lower margin poorly defined (10 YR 5/1)

2-Gray loam with charcoal, small stone bits, and pebbles (10 YR 5/1

3-Light brownish gray matrix with sandy mortar (10 YR 6/2)

4-Sterile dark gray clay (10YR 4/1)

Figure 7. Profile of East Wall of Area B, Unit 4. 
UNIT 2-Level 2 Plan
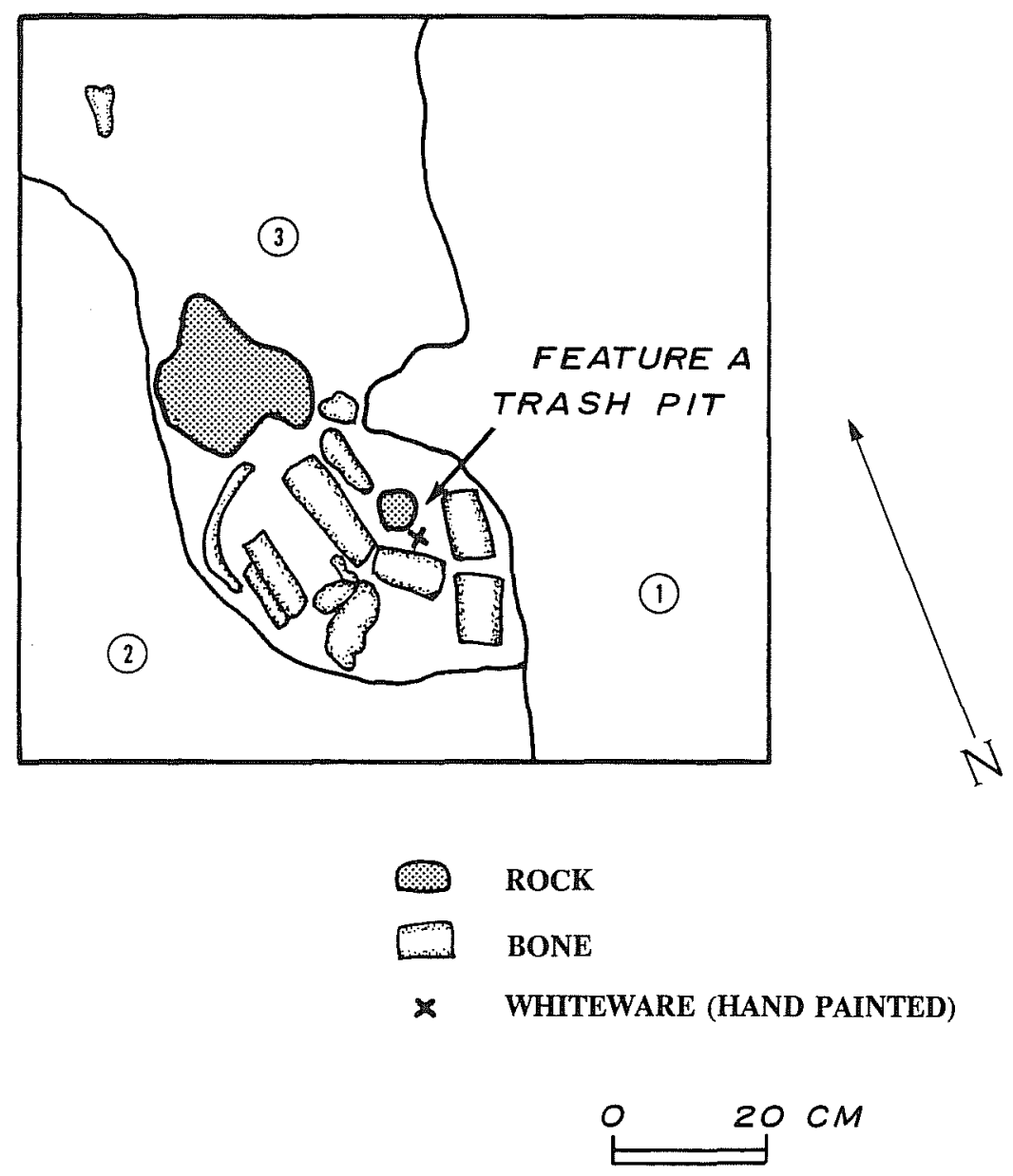

Figure 8. Level 2 Plan of Feature $A$ in Area C Excavations, Unit 2. 
Feature A was exposed as Level 2 was excavated; it continued through Level 3. The almost circular feature (approximately $45 \mathrm{~cm}$ in diameter) was somewhat enclosed by remains of the buttress; it contained a large quantity of butchered bone, numbering some 366 fragments (mostly cow bone) within a dark matrix. Two pieces of bottle glass, a modified flake, a mussel shell fragment, a piece of sheet copper, and a small quantity of ceramics were recovered; these included colonial period Goliad and lead-glazed sherds, an undecorated majolica sherd, along with a sherd of cobalt blue hand-painted whiteware (dating to the early 19th century) which was found atop the deposit. This primary midden deposit may have been associated with the occupation by the Yturri family (ca. 1823 to 1838), or possibly even earlier, prior to their occupation of the granary.

It can be concluded that little of the buttress was likely intact above ground when the trash pit was cut into its footing; the condition of the granary was already poor as early as 1806, as Huizar noted (Ivey, Thurber, and Escobedo 1990:165), and it was partially rebuilt by Yturri in order that the structure could be used. During the middle of the 19th century, subsequent to the Yturris' departure, the building was very much in ruins, as can be seen in a lithograph made by Lungkwitz ca. 1850 .

\section{DISCUSSION}

Wall foundations of the eastern convento wall were documented by the Area A excavations, with the northern edge of the rock wall alignment exposed at $5.88 \mathrm{~m}$ south of the exterior wall of the kitchen, extending the documented location approximately $0.5 \mathrm{~m}$ beyond the north edge recorded in the WPA outlines (see Fig. 2).

The existence of an arcaded opening for the eastern wall of the convento could not be verified with the Area A excavations, although the investigations indicated that the wall was probably continuous. The abrupt termination of the northern edge of the wall foundation seen in the upper strata was initially interpreted by the CAR investigators to indicate an arcaded opening; the arch placement would have corresponded to a centrally placed arch before a door as seen on the west arcade (consistent with, though not symmetrical with, the western facade). As the area north of the wall edge was excavated, however, it was found to have the appearance of being stone robbed, indicating that a rock wall had at one time existed in the area; indeed, several rocks were discovered in situ at a greater depth $(44$ to $60 \mathrm{~cm})$. Further work may be needed to resolve the questions regarding this structural feature; test units placed along the western arcaded wall, and at the closed-in arch area of the kitchen, for instance, may aid in clarifying both the original construction and filled-in rebuilding of such an arcaded feature, shedding light on its possible existence within the Area A location.

Ivey, Thurber, and Escobedo (1990:167) had noted, based on the 1860 deed transfer of the convento from Músquiz to Odin, that there were two closed arches forming the kitchen on the east porch. The one filled-in space is seen on the east wall of the kitchen (Fig. 3), and the second is that believed to have been located in the area of the CAR excavations, indicated by the remnants of vaulting extant in that section. A possible alternative location for the second closed-in space may be at the north or south end of the kitchen, although this appears less likely.

Remnants of the storeroom located between the granary and convento were apparently discovered with the finding of a consolidated adobelike surface, some 7 to $9 \mathrm{~cm}$ thick, that was uncovered in Unit 6 located at a depth of approximately $39 \mathrm{~cm}$; this likely represents the storeroom flooring. Its northern edge terminated within the unit. At Area B, remnants of a plaster, or adobelike, surface were also uncovered along the east wall of the excavations, located in Units 3 and 4; these may be further remains of the same storeroom flooring or that of Room 3, documented by Ivey (Ivey and Fox 1982:Fig. 4) in investigations conducted at the mission. The storeroom walls, however, were not uncovered during the CAR-UTSA investigations. The north wall could possibly be in place at the location of Unit 7 (which was left unexcavated) or perhaps at a deeper level in Unit 8. The south wall, based on a map (Ivey and Fox 1982:Fig. 5) studied subsequent to the excavations, may be located slightly north of the Area B position. 
Excavations at Area $\mathrm{C}$ documented the west granary wall footings and remnants of the wall buttress. A primary midden found within the buttress footings, Feature A, consisted largely of cow bone mixed with Spanish colonial material and topped by a early 19 th-century cobalt blue, hand-painted sherd. The finding supports the likelihood that deposits are more intact at this area, as does the topography of Area C, which is higher (over $30 \mathrm{~cm}$ ) than either Areas A and B. As Fox (1988:20) has also noted during earlier work along the eastern side of the convento, it appears that ground modifications have impacted deposits in this location, perhaps in earlier efforts to correct still extant drainage problems.

\section{ARTIFACT ANALYSIS}

In order to analyze the 2268 artifacts recovered during the excavation, the collection has been categorized into groups that reflect their association to the inhabitants (Table 1). This aids in the determination of what kinds of activities the inhabitants were engaged in and where they were performing these activities through time. From the first two levels, $86 \%$ of the artifacts were recovered, and were not delineated stratigraphically based on the age of the artifacts. This indicates that the soils have been highly disturbed. Nevertheless, through careful analysis of the collection we are able to add to the knowledge of the history of the mission and its inhabitants acquired in previous excavations.

\section{Ceramics}

Only cursory ceramic type descriptions will be given since the ceramic collection is small (186 sherds), and the type variability is limited. The interested reader can obtain more detailed descriptions from Davis and Corbin (1967:14-30), Schuetz (1969:7-26, 50-58), Fox, Bass, and Hester (1976:54-67), and Ivey and Fox (1981:30-35).

\section{Unglazed Wares}

Two types of unglazed wares were recovered during the excavation, Goliad and Valero wares. Of the 24 sherds recovered, 18 were of the Goliad ware type. The high percentage of Goliad ware is not unusual because it is by far the most common type found at 18th-century sites in the San Antonio River valley (Fox 1988:11). This local handmade ware is fired at low temperatures over open camp fires giving it a distinctive red to tan color with a black core and is tempered in varying amounts with ground bone, which appears as white flecks. Goliad ware is probably a direct continuation of local prehistoric ceramic traditions, continuing in use until the early 19th century (Ivey and Fox 1982:33). It has been suggested by Ivey and Fox (1982:34) that the continuation of the Goliad ware tradition argues for the survival of a local Indian subculture with a Hispanic veneer in the San Antonio River valley into the 19th century. One interesting piece of Goliad ware was part of a cup handle (Fig. 10,a). The handle attachment to the cup is still visible.

The other less frequently found unglazed ware is a wheel turned variety called Valero ware. It is evenly fired, probably in some sort of simple kiln at slightly higher temperatures, and it usually has only occasional white inclusions and is pinkish tan with a smooth homogeneous paste (Ivey and Fox 1982:33).

\section{Lead-Glazed Wares}

Fox (Ivey and Fox 1982:34) has divided lead-glazed wares into two basic types. The first group consists of relatively thick-walled, wheel-made bowls and ollas with a sandy orange paste and yellow orange to olive green glaze. Apparently used throughout the 18th century, 22 sherds can be assigned to this group.

The other type, called Galera ware, is thinner-walled and has a fine red paste with little if any sand. Galera ware, found throughout the southwest, appears in Texas about 1750 and is generally made in the form of chocolate pots and bean pots (Ivey and Fox 1982:34). There are 14 Galera ware sherds in the collection. 
TABLE 1. MISSION CONCEPCION ARTIFACTS

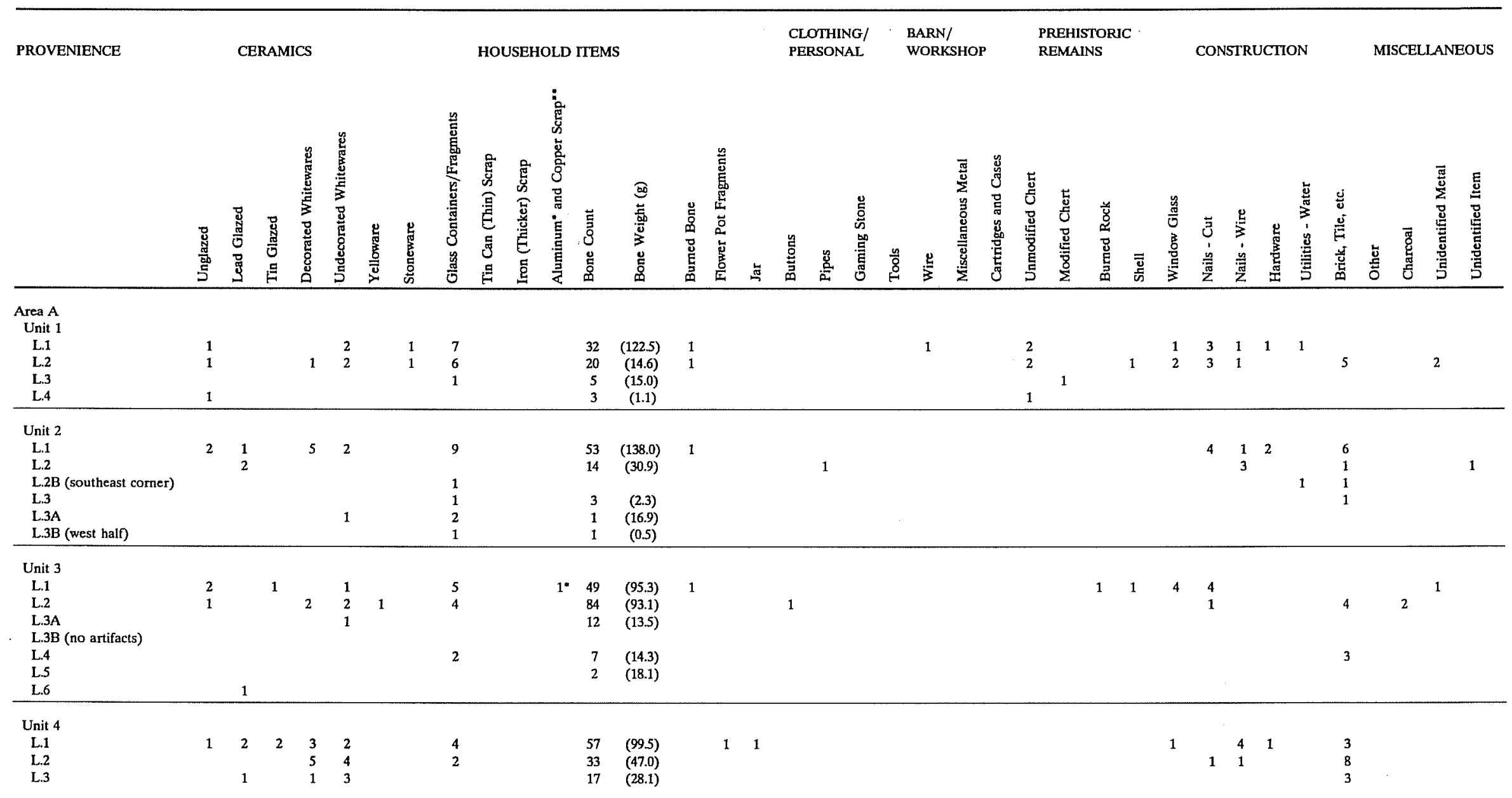


Table 1. (continued)

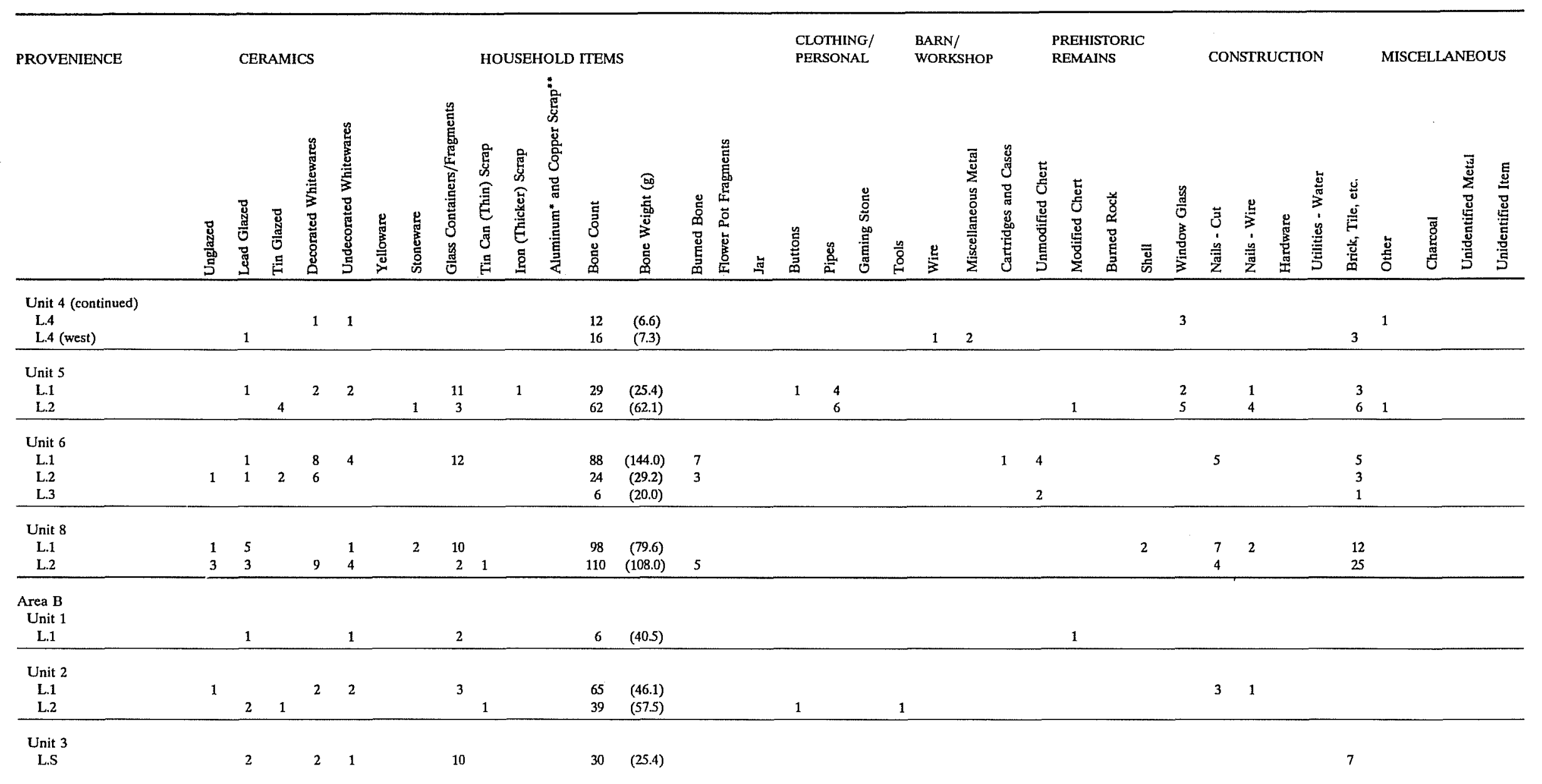


Table 1. (continued)

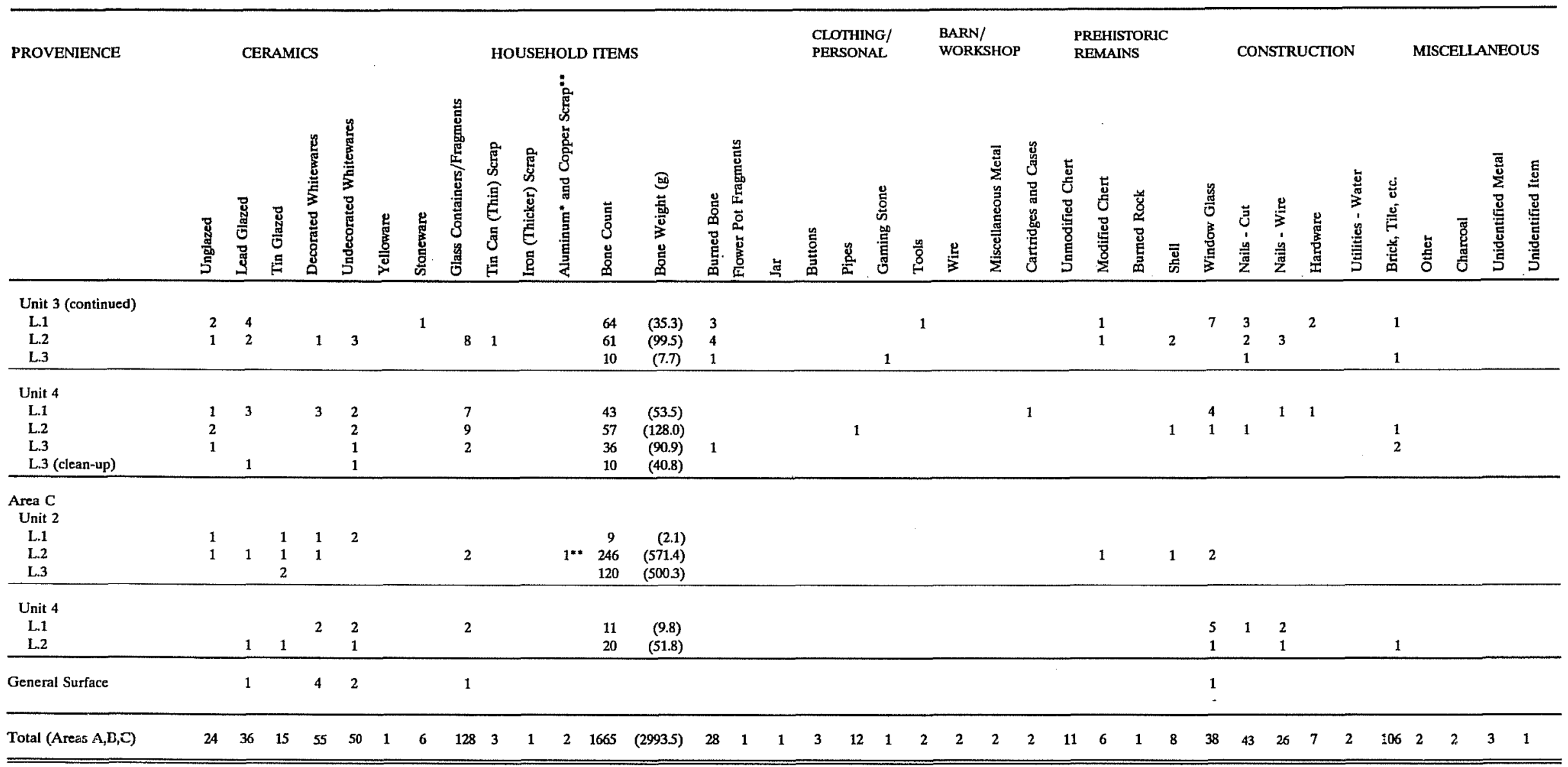




\section{Tin-Enameled Wares}

The tin-enameled wares, called majolicas, were made in Mexico, primarily in the city of Puebla, and brought to Texas throughout the 18th and early 19 th centuries. Decoration patterns and color combinations changed through time, making them useful chronological markers (Ivey and Fox 1982:34).

Of the 15 majolica sherds found, three represent the San Elizario Polychrome variety proposed by Gerald (1968:44) which dates from 1755 to 1780 . With the exception of a couple of undecorated sherds and unidentifiable blue-on-white sherds, the remainder of the majolica collection consists of sherds with a relatively hard, red paste and with decorations of blue green to green and reddish brown with touches of yellow. These are collectively known as Guanajuato wares, originating from the city of Guanajuato, in what is now Mexico, beginning in the early 1800s (Lister and Lister 1975:41). Distinguishing characteristics of this ware are its distinctive colors, its decorative elements (mostly geometric designs), the terra-cotta red paste, the poor quality of enamel application, and the greenish tint of the background enamel, as opposed to white or buff backgrounds of other majolicas. These may have been discarded by the Yturri family during their occupation of the granary from 1823 to 1838 .

\section{White Earthenwares}

When Anglo-American settlers arrived in Texas, they brought with them a preference for English-made whitewares. However, some of these wares were already present in the San Antonio area by the early 1830s or before (Fox 1986:122). The whitewares make up 57\% of the ceramic collection; there were 56 decorated and 49 undecorated whiteware sherds excavated. The decorated sherds include sponged, transfer printed (one was a blue and black transfer pattern; Fig. 10,b), banded slip (Fig. 10,c,d,f), hand painted (Fig. 10,e,h), and edged (Fig. 10,g) decorations. These patterns date to the early 19 th century, and most likely these sherds can also be associated with the Yturri family occupation.

One of the most interesting whiteware sherds was decorated with the Gaudy Dutch design. The basic design is done in underglaze blue, with touches of red painted overglaze, producing an effect similar to Japanese Imari decoration. These low quality ceramics designed to meet the demand for low cost, colorful designs, were made in Staffordshire, England, for export to America around 1810 to 1835 (Wolfe 1981).

\section{Yellow Ware}

A single cup handle made of yelloware (Fig. 10,i) was found in the second level of Area A, Unit 3, below two unglazed sherds and one tin-enameled sherd in the first level. Since the yelloware most likely dates from the late 19th to the early 20th century, and the sherds above it are from an earlier time period, this is indicative of the soil disturbance that has occurred in the area, no doubt at the time of the stone robbing of the foundation.

\section{Stoneware}

In the ceramic collection are six sherds. In the late 19 th and early 20 th century, many jugs, crocks, and jars were made of stoneware in Texas. Much of the stoneware came from the Meyer kiln near Atascosa, Texas (Greer and Black 1971; Fox 1988:14).

\section{Glass Containers}

The excavations produced 128 glass fragments (5.7\% of the total collection) in a variety of colors; unfortunately none of the fragments were diagnostic. The brown fragments were probably wine or beer bottles, the wine bottles could also be represented by the "black glass" and dark green fragments. Aqua 
Figure 10. Selected Artifacts.

a, Goliad ware cup handle;

b, blue and black transferware;

c, incised banded whiteware;

d, banded whiteware with worm pattern;

e, green, yellow, and brown hand-painted whiteware;

f, green, brown, and tan-banded whiteware;

g, whiteware with green cockle edge feather motif;

$\mathrm{h}$, blue and yellow hand-painted whiteware cup;

i, yelloware cup handle;

j, lower right first molar of capra hirca (domestic goat);

$\mathrm{k}$, upper molar of bos taurus (domestic cow);

l,m, Alderman pipe fragments;

n,o, Cutty pipe fragments with oakleaf pattern;

$\mathrm{p}$, double-hole composite button;

$\mathrm{q}$, single-hole bone button;

r, possible gunflint;

$\mathrm{s}$, perforator;

$\mathrm{t}$, sandstone gaming disc. 

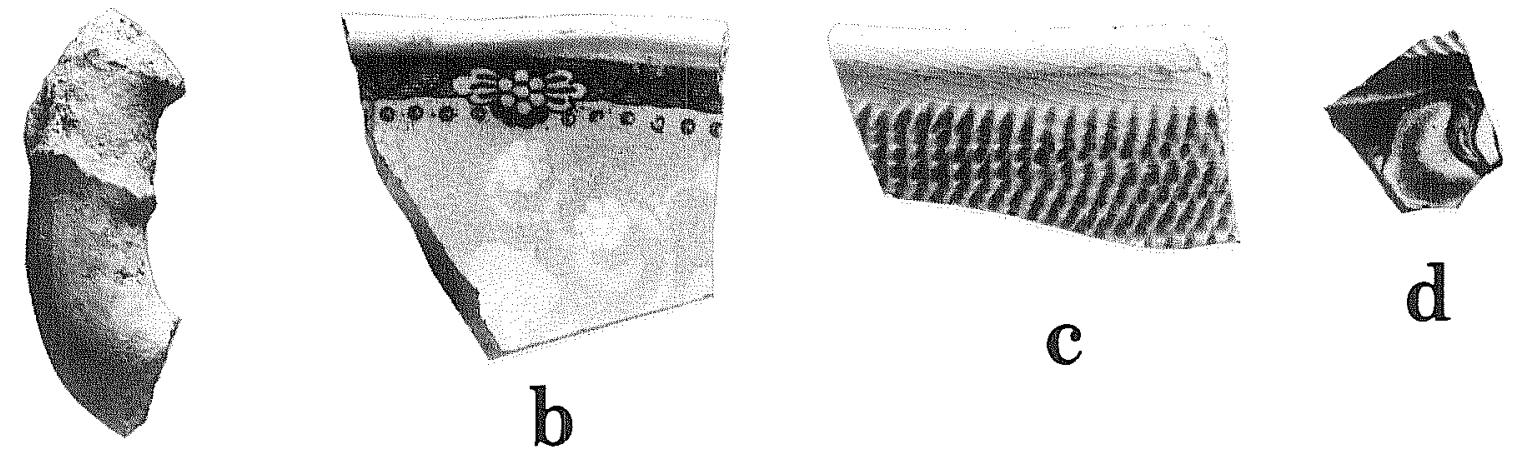

a
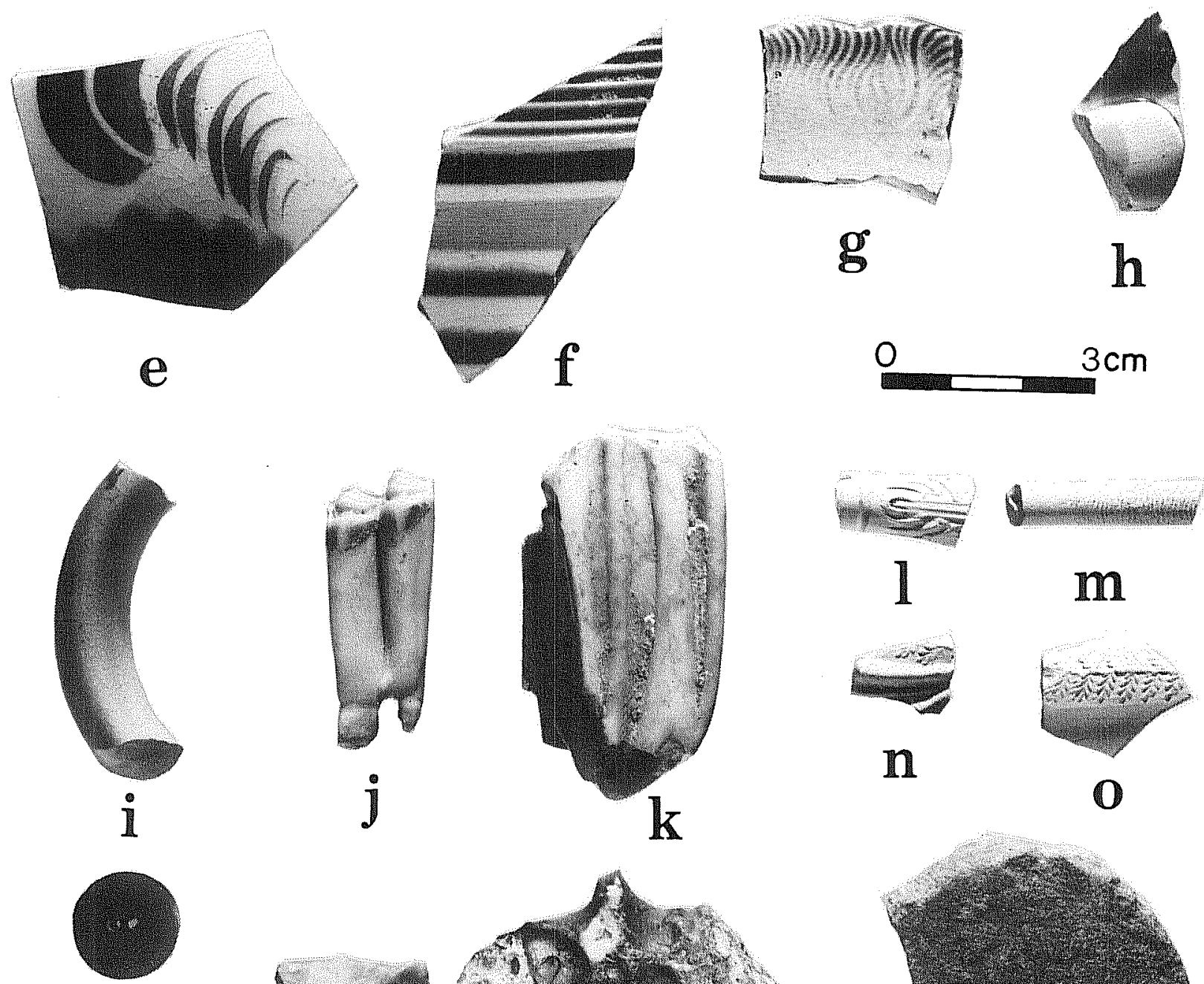

p
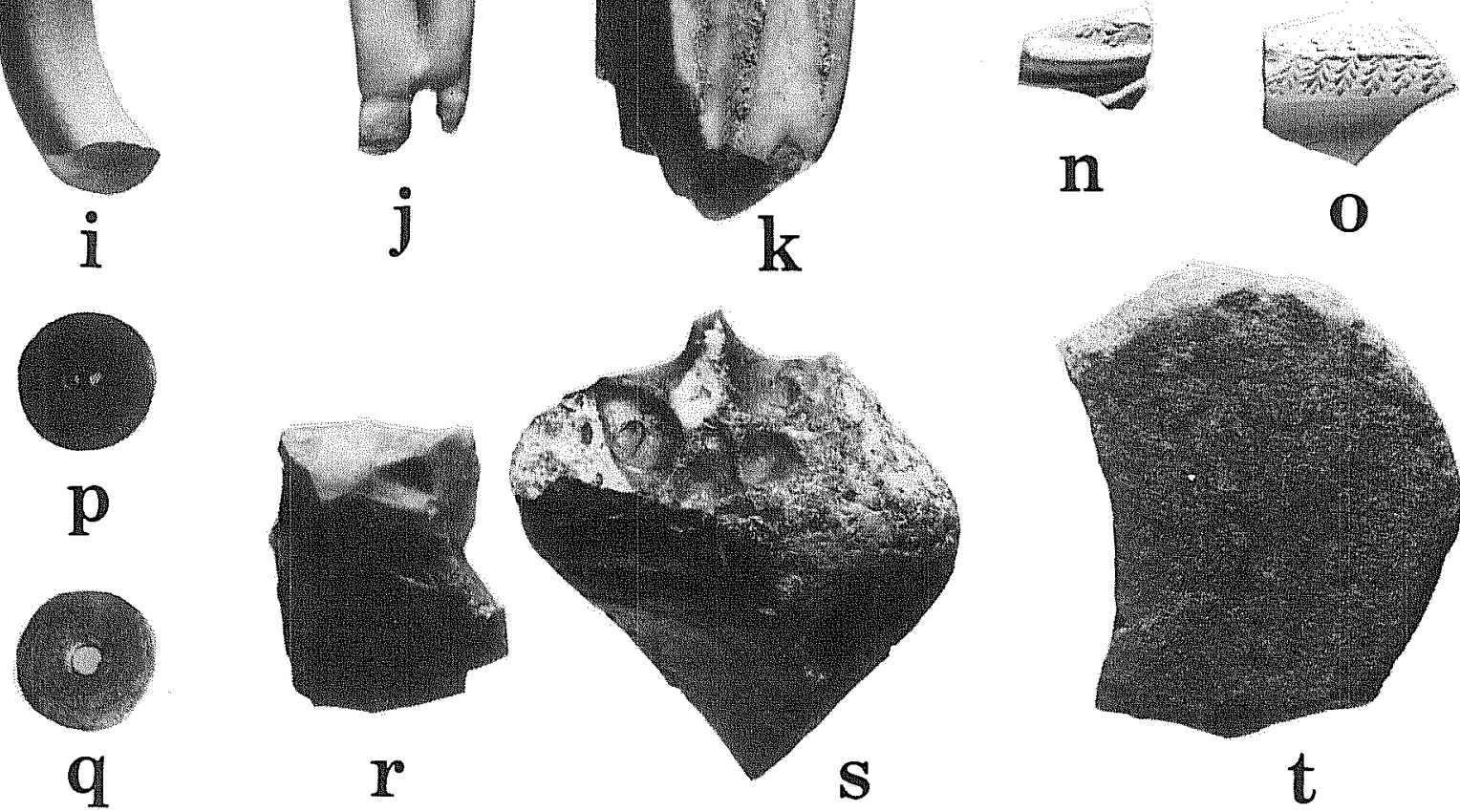

q

r

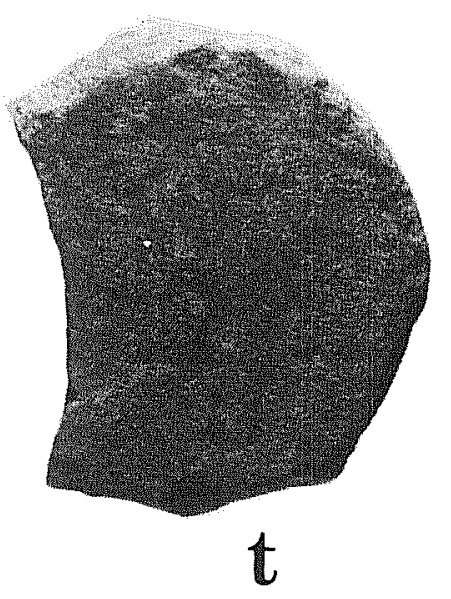


fragments are most likely from soda bottles, and the clear sherds may represent any number of container types.

\section{Thin Metal Scrap}

Only three pieces of thin metal scrap were found during excavation. These pieces are probably tin can fragments. In Area A, Unit 3, Level 1 some aluminum foil was found; in Area C, Unit 2, Level 2 a piece of flat copper scrap was found. Similar scraps are common in Spanish colonial collections.

\section{Subsistence}

\section{Animal Bone}

Recovered were 1655 bone fragments weighing 2993.5 grams, of which about half were butchered and only 28 were burned. The majority of the bones were of pig, goat, and cow (Fig. 10,j,k). This would not be unusual since these were the domestic animals kept at or near the mission as a food source. A large deposit of cow bones was found in Area C, Unit 2, from 10 to $40 \mathrm{~cm}$. It appears that a hole was dug into one of the buttresses of the granary to bury the bones. It is unknown if this location was purposely picked or if they unknowingly chose a very hard place to dig.

Other animal bones that are represented and may have been possible food sources include chicken, turkey, deer, raccoon, and squirrel. Rodent, dog, and small bird bones were also represented. With the lack of a clear stratigraphy because of intense soil disturbance, no further bone analysis was performed.

\section{Mussel Shell}

Eight shell fragments were also recovered without stratigraphy or in any concentration. In conjunction with the soil disturbance not much else can be said about the shell fragments, except to note they are a possible food source, and they generally seem to be found in association with chert flakes.

\section{Clothing and Personal Items}

\section{Pipe Fragments}

A total of 12 pipe fragments was found during the excavations, 10 from Levels 1 and 2 of Unit 5 in Area A, one from Area A, Unit 2, Level 2, and one from Area B, Unit 4, Level 2. The pipe stem from Area B and one piece from Area A had bore diameters of 3/32-inches, which along with their shape and construction suggests they may be parts of Alderman pipes (Fig. 10,1,m). These were first made in the middle 1700s and continued to be made into the $1800 \mathrm{~s}$. The pipes, later to be called straws because of their 18- to 24-inch stems, were fashionable with the gentry and as far as is known were the first pipes to have been given a specific name during their period of use (Ayto 1987:6).

The remaining stem fragments had bore diameters of $1 / 16$-inch, and along with the two bowl fragments have designs suggestive of a late-19th-century design known as Cutty Pipes with an oakleaf pattern (Fig. 10,n,o;Ayto 1987:9). Pipe production dramatically increased in the second half of the 19th century when Victorian businessmen exploited their use as an advertising medium. These were run-of-the-mill pipes called fancy clays or fancies and it would be difficult for a person not to be able to find a pipe connecting them with their occupation or interests. Clay pipe fragments are found all over the country, because not only 
was pipe smoking a popular pastime, but one 19th-century pipe factory alone could produce several thousand pipes every day (Ayton 1987:29).

\section{Buttons}

Three buttons were recovered. An unusual fragment of a square button made of porcelain, from Area A, Unit 3, Level 2, is otherwise unidentifiable or datable. A composition button (Fig. 10,p) was located in Area A, Unit 5, Level 1. These were first made in the 1850 s and continued in use until the turn of the century. A bone button (Fig. 10,q) found in Area B, Unit 2, Level 2, is $15 \mathrm{~mm}$ in diameter and has a single hole in the center. South (1964:119) has associated this type of button with the period between 1726 and 1776 . Five similar buttons were found during the excavations at Alamo Plaza in 1988, four of which were $12 \mathrm{~mm}$ and one $17 \mathrm{~mm}$ in diameter (Fox 1992).

\section{Chert}

The excavations produced 17 chert specimens. Of these, six were modified or possibly modified. One specimen (Fig. 10,s) is a secondary cortex flake that may have been fashioned to serve as a perforator; it measures $3.1 \mathrm{~cm}$ in length, $2.4 \mathrm{~cm}$ in width, and $1.0 \mathrm{~cm}$ in thickness. A possible gunflint (Fig. 10,r) from Level 3 of Area A, Unit 1, measures $3.1 \mathrm{~cm}$ in length, $2.4 \mathrm{~cm}$ in width, and $1.0 \mathrm{~cm}$ in thickness. Feature A from Area $C$ yielded a modified flake; two modified flakes and another that was possibly modified were recovered in Area B. Hester (1977:11) notes that such "casual tools" are found in large numbers at mission sites.

The remaining items consist of flakes and chips with no evidence of modification. The specimens were yielded in Units 1 and 6 of Area A; the majority from Unit 6 show evidence of burning.

\section{Gaming Stone}

One roughly circular (about 1.875 inch in diameter) sandstone gaming stone (Fig. 10,t) with a relatively smooth top and bottom was found in Area B, Unit 3, Level 3. These gaming stones are commonly found at Spanish colonial sites and are made of sandstone, lead-glazed, and Goliad ware fragments (Greer 1967:Fig. 30,b-e). Meskill (n.d.) notes that mission guidelines (Leutenegger 1976:140) record that mission Indians were avid players of games such as Patole (a game possibly similar to Parcheesi) and Chueca (a kind of hockey), often willing to gamble away almost all their belongings. These gaming stones could possibly be associated with these games.

\section{Workshop Items}

Part of a hoe and a screwdriver were found; these were not diagnostic and are of fairly recent design. Two pieces of wire and two of unidentifiable scrap iron were also recovered.

\section{Arms}

Two .22 caliber cartridge shells were found in Level 1 of Area A, Unit 6 and Level 1 of Area B., Unit 4. These are most likely of very recent deposit. 


\section{Construction Material}

The deposition of the artifacts of construction, which made up $9.8 \%$ of the total collection, like the ceramic deposits is indicative of soil disturbance. Construction materials, whether early or late, were found together at all levels.

\section{Window Glass}

Window glass (38 fragments) was found scattered throughout the excavations and at all levels. The vast majority of the fragments were $1.5 \mathrm{~mm}$ (1/16-inch) thick, though there were a few $3 \mathrm{~mm}$ (1/8-inch) thick. The thicker panes are most likely more recent.

\section{Cut Nails}

Cut nails are square in cross section and were used in Texas between ca. 1800 and 1900 (see Fontana and Greenleaf 1962:54). There were 46 cut nails recovered; they outnumbered wire nails 2 to 1 and were generally found in association with thinner window glass.

\section{Wire Nails}

Twenty-three wire nails were found, all in the first or second level. It was not until after ca. 1890 that wire nails could be found in the San Antonio area (Fox 1988:19). These more recent nails were found in almost every instance in association with the earlier cut nails, another indication of the widespread soil disturbance in the excavation area.

\section{Hardware}

The hardware consisted of six wood screws ranging in size from 0.75 to 1.25 inch and one 1.25 -inch-thick iron C-hook. All of these recent hardware items were found in Levels 1 and 2, but they were also found in association with Spanish colonial ceramics.

\section{Brick/Tile}

Recovered during the excavations were 106 fragments of brick and tile. Some of the more recent artifacts include several pieces of modern red brick, two fragments of ceramic sewer pipe, and one flower pot fragment. Most of the brick artifacts were fragments of locally made Spanish colonial tiles or ladrillos. These are found at all the San Antonio missions and were generally used for flooring, although they were occasionally also used in ceilings or for other special purposes.

\section{Miscellaneous Items}

Several metal items, all in the top two levels, were unidentifiable. Several paint fragments were found in Area A, Unit 5, Level 2.

\section{CONCLUSIONS}

The primary purpose of the project was to determine what cultural resources may remain in the courtyard area, so that future drainage and landscaping work might be planned and accomplished without destroying 
archaeological remains. In particular, the focus was on identifying and locating wall remains and checking them against maps made by previous investigators. Specifically, the excavations attempted to identify: the foundation of the eastern arcade wall, traces of arcade footings, whether a pilaster once stood against the east face of the arcade wall, the north and south walls of a storage room, and the location of a buttress against the granary wall.

The excavations showed that the eastern arcade wall of the second convento appears, in fact, to extend from the test pits in Area B to the kitchen area. There were not, however, any indications of arcade footings, but the foundation continued uninterrupted across Area A. Excavation of Area A disclosed that the foundation had been stone robbed, probably in the early 19th century, to judge from the comparative age of the artifacts jumbled together in the stone-robbed wall trench fill. Mixed in with the trench fill and extending across the original ground surface toward the west wall of the arcade area was a layer of roof fall from the collapse of the arcade (Fig. 3). No trace was found of the north or south wall of the storage room proposed to be located within the courtyard, nor were there indications of pilasters against the arcade wall. However, limitations of time prevented sufficient investigation of the area to state unequivocally that these do not exist.

As pointed out by Fox (1988:20), one mystery that still remains unsolved is what happened to the Spanish colonial floors and occupational debris. Once again the excavations did not reveal any clues to this mystery. Thus, while the excavations have shown that the knowledge gained in previous investigations does provide some predictive value, there are still many unknowns and surprises lurking only inches beneath the surface in this area.

\section{RECOMMENDATIONS}

The CAR-UTSA excavations posed a number of questions as work progressed; the restrictions of time and the extreme complexity of the deposits made it impossible to adequately pursue all leads. We suggest that it will be necessary to investigate a much larger area in order to be able to understand the complex evidences of construction, demolition, and reconstruction of the two convento buildings, the granary, and other structures such as the storeroom. It is particularly important that these additional investigations be done before any future landscaping or drainage are done. As demonstrated in these excavations, the archaeological evidence is still present but in a delicate condition, very close to the surface in many cases, and could easily be eradicated by hasty or careless alterations of the present ground surface.

\section{REFERENCES CITED}

Ayto, E. G.

1987 Clay Tobacco Pipes. Shire Publications Ltd., Aylesbury, United Kingdom.

Brown, $\mathrm{M}$.

n.d. Mission Road Realignment, Phase 2. Center for Archaeological Research, The University of Texas at San Antonio, Archaeological Survey Report in preparation.

Cisneros, J. A.

1980 San Antonio Missions National Historical Park, San Antonio, Texas, Statement for Management. U. S. Department of Interior and National Park Service.

Corner, W.

1890 San Antonio de Bexar: A Guide and History. Bainbridge and Corner, San Antonio, Texas. 
Davis, E. M. and J. E. Corbin

1967 Archeological Investigations at Washington-on-the-Brazos State Park in 1966. State Building Commission Archeological Program Report 5. Austin.

Fontana, B. L. and J. C. Greenleaf

1962 Johnny Ward's Ranch: A Study in Historic Archaeology. The Kiva 28:1-2.

Fox, A. A.

1986 Ceramics. In La Villita Earthworks (41 BX 677): San Antonio, Texas. A Preliminary Report of Investigations of Mexican Siege Works at the Battle of the Alamo, assembled by J. $\mathbf{H}$. Labadie: 107-127. Center for Archaeological Research, The University of Texas at San Antonio, Archaeological Survey Report 159.

1988 Archaeological Investigations at Mission Concepción, Fall of 1986. Center for Archaeological Research, The University of Texas at San Antonio, Archaeological Survey Report 172.

1989 Monitoring of Utility Trenches as Mission Concepción, San Antonio, Texas, 1988. Center for Archaeological Research, The University of Texas at San Antonio, Archaeological Survey Report 180.

1992 Archaeological Investigations in Alamo Plaza, 1988 and 1989. Center for Archaeological Research, The University of Texas at San Antonio, Archaeological Survey Report 205.

Fox, A. A., F. A. Bass, Jr. and T. R. Hester

1976 The Archaeology and History of Alamo Plaza. Center for Archaeological Research, The University of Texas at San Antonio, Archaeological Survey Report 16.

Gerald, R. E.

1968 Spanish Presidios of the Late Eighteenth Century in Northern New Spain. Museum of New Mexico Research Records 7. Museum of New Mexico Press.

Greer, J. W.

1967 A Description of the Stratigraphy, Features, and Artifacts from an Archeological Excavation at the Alamo. State Building Commission Archeological Program Report 3, Austin.

Greer, G.H. and H. Black

1971 The Meyer Family: Master Potters of Texas. Trinity University Press, San Antonio.

Habig, M. A.

1968 The Alamo Chain of Missions, A History of San Antonio's Five Old Missions. Franciscan Herald Press, Chicago.

1971 Marion A. Habig to Curtis Tunnell, August 12, 1971. Documents pertaining to excavations at Mission Purísima Concepción. On file, Texas Historical Commission, Austin. 
Hester, T. R.

1977 The Lithic Technology of Mission Indians in Texas and Northeastern Mexico. Lithic Technology 6:9-12.

Ivey, J. E. and A. A. Fox

1981 Archaeological Survey and Testing at Rancho de las Cabras, Wilson County, Texas. Center for Archaeological Research, The University of Texas at San Antonio, Archaeological Survey Report 104.

1982 Archaeological Investigations at Mission Concepción and Mission Parkway. Center for Archaeological Research, The University of Texas at San Antonio, Archaeological Survey Report 114. Manuscript on file.

Ivey, J. E. and M. B. Thurber

1984 The Missions of San Antonio, A Historic Structures Report and Administrative History. Part 1: The Spanish Colonial Missions, edited by Tom Ireland. National Park Service, Southwest Cultural Resources Center, Santa Fe, New Mexico. Draft report on file at the Center for Archaeological Research, The University of Texas at San Antonio.

Ivey, J. E., M. B. Thurber and S. Escobedo

1990 Of Various Magnificence, The Architectural History of the San Antonio Missions in the Colonial Period and the Nineteenth Century. National Park Service Southwest Regional Office, Southwest Cultural Resources Center, Professional Papers No. 11. Draft report on file at San Antonio Missions National Historical Park, San Antonio.

Labadie, J. H.

1989 Archaeological and Historical Investigations for the Mission Road Realignment Project. Center for Archaeological Research, The University of Texas at San Antonio, Archaeological Surey Report 173.

Leutenegger, B.

1973 The Zacatecan Missionaries in Texas 1716-1834: Excerpts from the Libros de las Decretos of the Missionary College of Zacatecas, 1701-1828. Texas Historical Survey Committee, Office of the State Archeologist Report 23. Austin.

1976 Guidelines for a Texas Mission: Instructions for the Missionary of Mission Concepción in San Antonio. Old Spanish Missions Historical Research Library, Out Lady of the Lake University, Documentary Series 1. San Antonio.

Lister, F. C. and R. H. Lister

1974 Majolica in Colonial Spanish America. Historical Archaeology 8:17- 52.

Matson, D. S. and B. L. Fontana, editors and translators

1977 Friar Bringas Reports to the King: Methods of Indoctrination on the Frontier of New Spain, 1796-97. The University of Arizona Press, Tucson. 
Meskill, F.

n.d. Archaeological Test Excavations at Mission San Francisco de la Espada. Center for Archaeological Research, The University of Texas at San Antonio, Archaeological Survey Report, in preparation.

Ortiz, F. X.

1745 Visita de las Missiones hecha, de N.M.P. Comm.o Gr.al, Fr. Juan Fogueras, porelp. Fr. Franco Xavier Ortiz, en el año de 1745. Microfilm Archive, Roll 9, frames 1265-1285, October 11, 1745. Old Spanish Missions Historical Research Library, Our Lady of the Lake University, San Antonio.

1955 Razón de la Visita a las Missiones de la Provincia de Texas, 1765. Three volumes. Vargas Rea, editor. Biblioteca de Historiadores Mexicanes, Mexico.

Schmitz, J. W.

1965 Mission Concepción. Texian Press, Waco.

Schuetz, M. K.

1969 The History and Archeology of Mission San Juan Capistraño, San Antonio, Texas. Description of the Artifacts and Ethnohistory of the Coahuiltecan Indians. State Building Commission, Archeology Program Report 11. Austin.

Scurlock, D. and D. E. Fox

1977 An Archeological Investigation of Mission Concepción, San Antonio, Texas. Office of the State Archeologist Report 28. Austin.

South, S.

1964 Analysis of Buttons from Brunswick Town and Fort Fischer. The Florida Anthropologist 17 (2):113-133.

Taylor, F. B., R. B. Hailey, and D. L. Richmond

1966 Soil Survey, Bexar County, Texas. U. S. Department of Agriculture, Soil Conservation Service in cooperation with the Texas Agricultural Experiment Station, Series 1962 (12).

Webb, W. P., editor

1952 Handbook of Texas. Vol.2. Texas State Historical Association, Austin.

Wolfe, A. Y.

1981 Anne Y. Wolfe to Anne A. Fox, April 24, 1981. Documents pertaining to Gaudy Dutch ceramics. On file, Center for Archaeological Research, The University of Texas at San Antonio. 